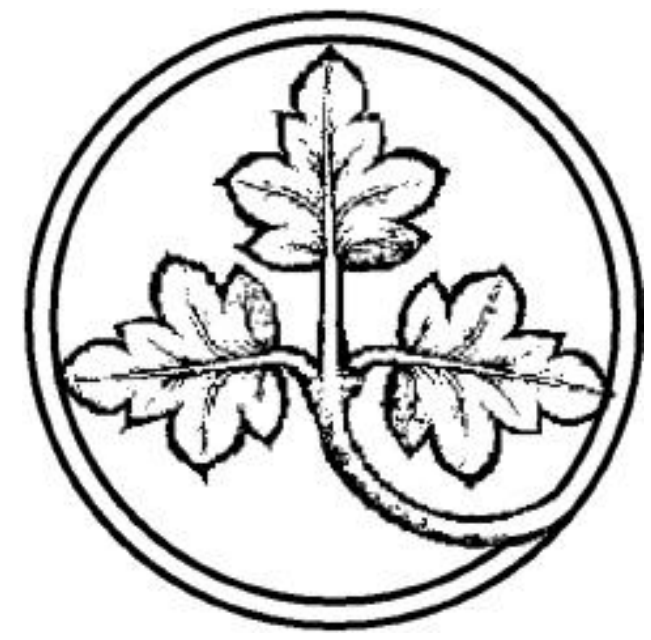

Gemeinschaftsgüter: Recht, Politik und Ökonomie

\author{
Preprints \\ aus der Max-Planck-Projektgruppe \\ Recht der Gemeinschaftsgüter \\ Bonn \\ 2000/14
}

Private Actors on the Rise? The Role of Non-State Actors in Compliance with International Institutions

VOn

Tanja A. Börzel 


\title{
Private Actors on the Rise? The Role of Non-State Actors in Compliance with International Institutions
}

\author{
Tanja A. Börzel
}

July 2000

Max-Planck-Projektgruppe Recht der Gemeinschaftsgüter, Poppelsdorfer Alle 45, 53115 Bonn 


\section{Private Actors on the Rise? The Role of Non-State Actors in Compliance with International Institutions ${ }^{1}$}

\section{Introduction}

Are private actors on the rise - crowding out the states as the traditional stakeholders in world politics? There is a growing body of literature observing an increasing presence of multinational corporations (MNCs; Hirst and Thompson 1996; Drucker 1997), International Non-Governmental Organizations (INGOs; Boli and Thomas 1999; Weiss and Gordenker 1996), epistemic communities (Haas 1992), transnational advocacy coalitions (Keck and Sikkink 1998; Sikkink 1993), terrorist groups (Deutch 1997) and other criminal organizations, transnational social movements (Smith, Chatfield, and Pagnucco 1997; Tarrow 2001), and corporate private regimes (Haufler 1995; Cutler, Haufler, and Porter 1999). Some go as far as to argue that we witness the emergence of a global (capitalist) civil society, which is overtaking the state-world as we have known it (Omahe 1990; Strange 1996; Amin 1997; Boli and Thomas 1999; Czempiel 1999).

Yet, there is little evidence for the claim that nation-states are doomed to become, at best, side-players in world politics (Reinicke 1998; Breitmeier and Rittberger 2000). (Transnational) private actors have a significant role in 'global governance'. But their influence varies significantly, both across time and issues. Moreover, the relationship between state and non-state actors is not necessarily zero-sum. The major challenge for theorizing about non-state actors in world politics, therefore, is not only to demonstrate that they matter but explain where, when, and how they matter. This paper takes issue with these challenges by looking at the role of private actors in compliance with international institutions. Many empirical studies point at the importance of non-state actors in bringing about compliance (Cook 1996; Smith 1997; Korey 1998; Wapner 2000). But these explanations have been rarely turned into generalizable propositions. Nor have they been tested systematically against more state-centred explanations of compliance.

1 For comments on earlier versions of this paper I am thankful to Christoph Engel, Adrienne Héritier, Katharina Holzinger, Christian Joerges, Dirk Lehmkuhl, Leonor Moral, Thomas Risse, Jens Steffek, Cornelia Ulbert, Jacques Ziller, and Michael Zürn. 
The first part of the paper clarifies the concept of compliance applied in this study and the distinction made between public and private actors. The second part reviews prominent approaches to compliance in the International Relations literature. I contrast systemic, statecentred theories with subsystemic, society-based approaches as the basis for private actor explanations of compliance. The different approaches allow me to derive a series of hypotheses about the role of private actors in compliance with international institutions. The last part, finally, suggests a research design for empirically testing the different hypotheses using the European Union as a critical case.

The paper is the first step in a larger research project on the impact of private actors on compliance with international institutions. A quantitative analysis of EU member state compliance with Community Law over 20 years will eliminate most of the conventional, state-centred explanations, which are too simplistic to account for the variation in compliance observed. A qualitative comparative case study will explore when and how private actors take action for, or against, compliance, and to what extent their action facilitates or inhibits compliance. My ultimate aim is to develop a model, which specifies conditions under which private actors are likely to facilitate or inhibit compliance with international institutions. The last part of my project will analyze to what extent compliance with international institutions affects the level and form of societal activism, potentially triggering changes in state-society relations on one hand, and in the balance of power between the three branches of government, on the other hand.

\section{Compliance and the Distinction between Public and Private Actors}

\subsection{What is Compliance?}

The literature on compliance presents a Babylonian variety of understandings and definitions of the concept. Moreover, the distinction between compliance and related concepts, such as implementation and effectiveness, is often not clear. For the sake of this study, compliance is defined as rule-consistent behaviour of those actors, to whom a rule is formally addressed and whose behaviour is targeted by the rule. ${ }^{2}$ While states are the addressees of most international norms and rules, and, hence, are formally responsible for compliance, they are not necessarily the main or exclusive targets. Many rules target the behaviour of non-state actors, too.

2 Actors targeted by a rule are not identical with actors affected by a rule. Unlike affected actors, a rule directly requires target actors to change their behaviour. Consumers are affected by foodstuff rules, but it is the food industry which has to change its production behaviour. 
Table 1: Public and Private Actors as Addressees and Targets of International Rules

\begin{tabular}{|l|c|c|}
\hline $\begin{array}{c}\text { Rule addressee } \\
\text { Rule target }\end{array}$ & Public Actors & Private Actors \\
\hline Public Actors & $\begin{array}{c}\text { human rights } \\
\text { security } \\
\text { free trade }\end{array}$ & \\
\hline Private Actors & $\begin{array}{c}\text { environment } \\
\text { health and safety }\end{array}$ & $\begin{array}{c}\text { political risk insurance } \\
\text { commercial arbitration }\end{array}$ \\
\hline
\end{tabular}

The distinction between addressees and targets of a rule is important for defining the relative role of public and private actors in compliance. If states are only the addressees of a rule but not the main targets, the ultimate responsibility for compliance lies with private actors. Beyond formal incorporation into national law, the role of public actors is confined to effectively monitoring and enforcing international rules in order to ensure compliance. Unlike in cases where states are both addressees and targets of a rule, problems of 'involuntary noncompliance' are more likely to arise (Börzel 2000a).

Many studies explore the extent to which international norms and rules are complied with by their addressees, i.e. they focus on states only (Jacobsen and Weiss Brown 1995; Zürn 2000; Weiler 1988; Krislov, Ehlermann, and Weiler 1986). The distinction between addressees and targets of a rule helps to clarify the relationship between compliance on one hand, and implementation with its three major elements, output, outcome, and impact/effectiveness, on the other hand. Implementation refers to the putting into practice of policies or rules. Drawing on Easton's system theory approach, implementation studies often distinguish between three different stages of the implementation process:

- output: the legal and administrative measures required to achieve the policy goal (formal and practical implementation)

- outcome: the effect of the policy measures on the behaviour of the target actors

- impact: the effect of the policy on the socio-economic environment (effectiveness)

This typology, however, is far from being consensual. Parts of the international regimes literature refer to outcome as regime effectiveness, although the equation is not complete, because regime effectiveness is defined as rule-consistent behaviour of states only, neglecting the behaviour of private actors as potential targets of a regime (Rittberger 1995a; Zürn 1997). ${ }^{3}$

3 The Tübingen School of regime theory, a research team led by Volker Rittberger, added regime effectiveness as a fifth element to Krasner's famous definition of regimes as "a set of implicit and explicit principles, norms, rules, and decision-making procedures around which actors' expectations converge in a given area of international relations" (Krasner 1983b.). This was felt necessary in order to distinguish regimes from mere promises or contracts to which the parties may or may not live up (Rittberger 1995b). American scholars, however, argued that it would be "circular reasoning to identify regimes on the basis of observed behaviour, and then use them to 'explain' observed behaviour" (Keohane 1995.). The transatlantic debate resulted in a compromise according to which a set of principles, norms, rules, and procedures must have "prescriptive status in the sense that actors refer regularly to the rules both in characterizing their own behaviour and in commenting on the behaviour of others" (Rittberger 1995). For the study of compliance, the introduction of 
Others, by contrast, measure effectiveness in terms of the impact of a regime or policy defined as the extent to which they make a difference to their environment as compared to what would have occurred in the absence of the regime or policy (Levy, Young, and Zürn 1995; Bernauer 1995; Nollkämper 1992. The distinction between outcome and impact/effectiveness seems justified if a change in the behaviour of target actors is not assumed to necessarily solve the problem to which the regime or policy is addressed. Effectiveness, thereby, becomes an important measure for the problem-solving capacity of a regime or policy, to which some scholars, however, refer as regime impact (Rittberger 1995a; Müller 1993).

Given the definition of compliance as rule-consistent behaviour of both the addressees and the targets of a rule, this study focuses on output and outcome, while impact, effectiveness, and problem-solving capacity are excluded.

With respect to output, compliance with a rule requires that:

- the rule is completely and correctly incorporated into national legislation and/or conflicting national rules are amended or repealed (formal compliance),

- the administrative infrastructure and resources are provided to put the objectives of the rule into practice and to monitor the rule-consistent behaviour of the target actors of the rule (practical compliance),

- the competent authorities encourage or compel rule-consistent behaviour of the target actors by effective monitoring, positive and negative sanctions, and compulsory corrective measures (practical compliance, monitoring and enforcement)

Concerning outcome, compliance with a rule presupposes that:

- the target actors take the necessary action to make their behaviour consistent with the requirements of the rule,

- $\quad$ the target actors refrain from action violating the rule. ${ }^{4}$

a behavioural component to the regime definition is meaningful, too, because actors can only violate a norm or rule if they accept it in the first place (Kratochwil 1995).

4 Note that outcome is not measured in terms of effectiveness. To what extent, for instance, industry complies with air pollution rules is not measured by an improvement of the air quality in a given region (which could be also caused by external factors) but whether the polluters have implemented measures to reduce air pollution as required by the rule. If these measures actually help fighting air pollution is an altogether different matter, which relates to questions of effectiveness rather than compliance. 


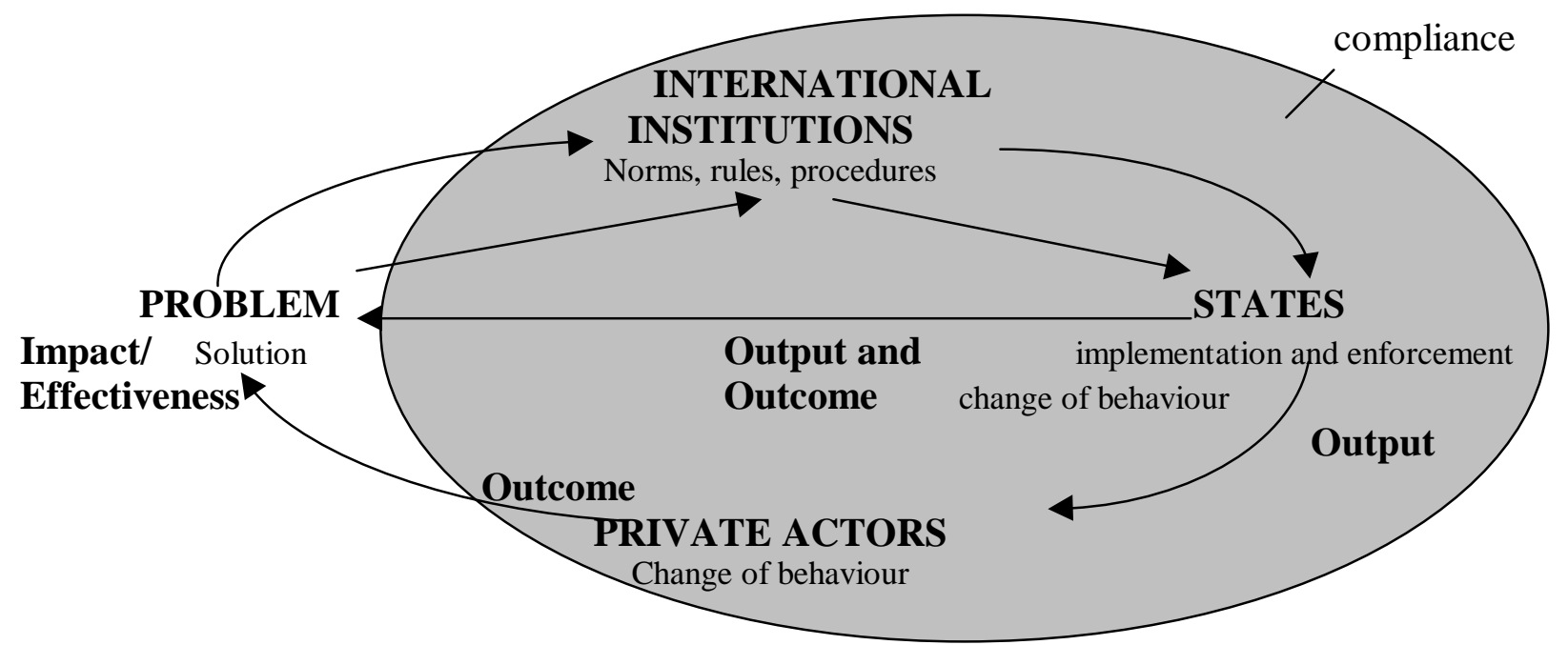

The definition of compliance as "output + outcome" entails a procedural understanding, which contrasts with a conceptualization of compliance as a binary category. The simple dichotomy of compliance $v s$. non-compliance is usually too static to measure a dependent variable, which consists of multiple dimensions. Rule-consistent behaviour is the ultimate measure for compliance. But it is often the result of a process of interpretation, contestation, and negotiation, of cooperation and conflict, whose main purpose is to reconcile divergent interests, interpretations, and problem perceptions (Chayes and Chayes Handler 1995; Snyder 1993; Windhoff-Héritier 1980; Mayntz 1983). In many cases, non-compliance is involuntary rather than deliberate. Thus, states most of the time do not simply refuse to comply with an international rule (defiance) or strive to secretly evade it (cheating). On one hand, they often ask for more time for implementation because of strong domestic opposition or the lack of necessary resources, or both. Non-compliance may also be justified by 'recalcitrant' subnational authorities bearing the main responsibility for implementation or by political changes, such as a change in government. In such cases of 'involuntary non-compliance', where states are willing to comply but lack the necessary economic, administrative, or political capacity, the issue of non-compliance as such is not contested. On the other hand, member states often object that their (refraining from) action constitutes an issue of noncompliance. They argue, for instance, that the rule is not applicable to the issue under consideration or they claim that the issue qualifies as one of the exceptions permitted by the rule. In order to understand and explain the mechanisms through which compliance evolves, one has to study the whole process rather than merely focusing on the outcome of it. Ambiguous and imprecise rules are particularly prone to become subject of contesting interpretations. 


\subsection{Public and Private Actors}

The distinction between public and private actors departs from state-centric approaches to compliance, which have been dominant in the field of International Relations (see below). In order to explore the role of private actors in compliance with international rules, the state cannot be treated as a unitary actor but has to be unpacked. Public (state) actors (policymakers, bureaucracies) are distinguished from private (non-state) actors, who do not operate on behalf of a state or an international organization. Within private actors, we can distinguish between for-profit, economic actors (e.g. corporations, interest groups) and not-for-profit, societal actors (e.g. voluntary organizations, social movements, advocacy coalitions). Economic actors aim foremost to produce financial wealth and are driven by the goal of maximizing profit. They are less concerned with solving common problems or advancing a particular political agenda. Societal actors, by contrast, are usually devoted to addressing public issues. Needless to say that these public issues are not necessarily 'progressive' or in the general interest of the public good. The organization of Aryan Nations, which strives to generate solidarity across borders among white people of European descent, is only one example of an INGO pursuing a 'public bad' (racism) rather than a 'public good' (Ridgeway 1995).

\section{Explaining Compliance with International Institutions}

\subsection{Organizing the Field}

This study turns to the International Relations (IR) literature as a starting point for theorizing about compliance. Admittedly, traditional IR theories are a poor basis for exploring the role of private actors in compliance because of their state-centric perspective. But they serve as the null hypotheses against which more complex, society-centred approaches shall be tested. Moreover, liberalism as one of the major IR paradigms as well as constructivist approaches, which, by now, have firmly established themselves in the field, provide ample room for developing private-actor based explanations of compliance. As states are the addressees and often also the targets of international rules, their behaviour is crucial for compliance. And explaining state behaviour is what most International Relations theories aspire. Finally, unlike implementation research in the field of public policy, IR scholars have not given up on developing generalizable claims about compliance, in spite, or maybe because of, the complexity of the issue.

There are many ways in which International Relations theories can be organized and classified. For the research on compliance, it is most useful to distinguish IR theories according to their level of analysis and the logic of action, to which they subscribe:

1) level of analysis: systemic versus subsystemic versus integrative theories ${ }^{5}$

2) logic of action: rationalist versus constructivist versus integrative theories

5 Waltz distinguishes a third level, the individual-level explanations, which look to the personal or psychological characteristics of individual statesmen (Waltz 1959). Robert Jervis even includes a forth level: bureaucratic processes (Jervis 1976). 
The level of analysis allows to distinguish between theories according to the relative role, which they attribute to public and private actors in compliance (do private actors matter?). The logic of action, which actors follow, refers to differences between theories with respect to the way in which they see private actors influence compliance (how do private actors matter?). The relationship between the two dimensions is orthogonal. Rationalist and constructivist approaches can be either systemic or subsystemic. The various combinations of the two dimensions generate different compliance mechanisms privileging different types of actors.

Figure 2: International Relations Theories and the Role of Private Actors

\begin{tabular}{|c|c|c|c|}
\hline systemic & \multirow{2}{*}{$\begin{array}{l}\text { Neorealism } \\
\\
\quad \text { Neoliberal } \\
\text { Institutionalism }\end{array}$} & \\
\hline \multirow{3}{*}{$\begin{array}{l}\text { Do private } \\
\text { actors matter } \\
\text { Privileged actors } \\
\text { Subsystemic } \\
\text { society-centred }\end{array}$} & & & $\begin{array}{l}\text { Statist Constructivism } \\
\text { English School of Realism }\end{array}$ \\
\hline & $\begin{array}{l}\text { Two-level } \\
\text { games }\end{array}$ & $\begin{array}{l}\text { Transnational } \\
\text { Relations }\end{array}$ & Sociological Institutionalism \\
\hline & Liberalism & $\begin{array}{l}\text { Domestic } \\
\text { Structures }\end{array}$ & Society-centred Constructivism \\
\hline \multicolumn{3}{|c|}{$\begin{array}{l}\text { rationalist } \\
\text { logic of consequentialism }\end{array}$} & $\begin{array}{l}\text { constructivist } \\
\text { logic of appropriateness }\end{array}$ \\
\hline
\end{tabular}

\section{Systemic versus Subsystemic Approaches}

The level of analysis refers to the location of the causes of state behaviour by classifying competing explanations according to the units in which they are conceptualized (Waltz 1959; Singer 1960; Singer 1961).

Systemic theories focus on the international level for explaining state behaviour. The structure of the international system - the distribution of power, economic dependencies, international institutions - define both the interests of states and their capacity to pursue these interests. Marxist approaches, such as world-systems theories and the dependency literature, focus on the economic structure of the international system, which gives states the preference for expansion and gain (Wallerstein 1974; Chase-Dunn 1989; Frank 1969; Cardoso and Faletto 1979). Neorealist theories emphasize the distribution of material capabilities in the international system as well as its anarchic nature. In the absence of a central power able to enforce state commitments, states face the constant threat of being conquered, occupied, or made subservient. As a result, states are most concerned about maximizing the chances of their survival by increasing their political and economic power vis-à-vis their rivals (Waltz 1979; Grieco 1988; Mearsheimer 1994/95). Neoliberal Institutionalist approaches share the neorealist assumption about the anarchic structure of the international system and the 
emphasis on the distribution of material capabilities among states. Yet, they stress that the structure of the international system does not merely give rise to competing interests among states. Due to relations of interdependence, states develop mutual interests, e.g. in liberalizing trade or protecting the environment (Keohane 1984; Keohane 1989a; Oye 1986). Statist constructivists, like Alex Wendt (Wendt 1992; Wendt 1999), as well as the English School of Realism (Wight 1966; Bull 1977), finally, do not limit structures to material and economic features but stress that socially constructed norms and rules, and shared beliefs also shape and motivate states.

Despite considerable differences, systemic approaches share some basic assumptions. The causes of state behaviour are external, that is located in the international system. States are treated as if there were unitary actors. For their predominantly state-centric perspective, ${ }^{6}$ systemic approaches do not attribute any significant role to (trans)national private actors in international politics, either in the formulation or the implementation of international rules. Therefore, they will provide the null-hypotheses for this study.

Subsystemic theories open the black box of the state. They focus on the political institutions, the society, and the culture of individual states to explain state behaviour in world politics. Andy Moravcsik aptly summarized the major difference between systemic and subsystemic approaches: "State behaviour does not respond to the international system - it constitutes it" (Moravcsik 1993: 5). There are three major strands of subsystemic theories.

First, society-centred approaches focus on the pressure from domestic social groups through legislatures, interest groups, elections, and public opinions in explaining state behaviour. Liberal pluralist theories conceive of states as political systems for the authoritative allocation of values in a given society (Easton 1965). Public actors are constrained by societal pressures which evolve from the political process in which societal interests compete. Political decisions are analyzed predominantly in terms of the preferences and strength of private actors (Dahl 1961). Power elite theories contend that not all societal actors have equal political power and that political processes are dominated by concurring interests of business and political elites (Mills 1956). Liberal theories in International Relations draw on both pluralist and power elite approaches. They derive state preferences from demands by domestic actors, who strive to maximize their material and immaterial welfare (Moravcsik 1997a; Milner 1988). The representative institutions of the state translate societal demands into state preferences. Society-centred constructivism, by contrast, points at the importance of collectively shared values, beliefs and identities of societal actors which shape state interests and identities (Risse-Kappen 1995b; Katzenstein 1996; Ulbert 1997b). Instrumental Marxism and the theory of state-monopolistic capitalism, finally, conceptualize the state as the executive agent of the ruling (capitalist) class. Despite considerable differences between liberal and marxist approaches, both theorize the state more or less away. Public actors are reduced to be transmission belts of private interest groups, elites, or ruling classes.

6 This is not to argue that all systemic approaches are necessarily state-centred while all subsystemic approaches are society-centred. Strictly speaking, the two distinctions are orthogonal. Yet, with the exception of world systems theories and interdependence theories, systemic approaches are predominantly statecentred, particularly when it comes to explaining compliance. The same holds true for the society-centred focus of most subsystemic approaches, with the exception of bureaucratic politics maybe (see below). 
Second, state-centred approaches strive to "bring the state back in" subsystemic approaches (Evans, Rueschemeyer, and Skocpol 1985). They focus on sources of state behaviour within the administrative and decision-making apparatus of the executive branch of the state. States are treated as actors in their own rights pursuing their own goals of power and wealth in the absence of, or even against, strong societal forces. Statist IR scholars argue that the domestic power of states over society stems from the need to preserve the internal cohesion of the nation (law and order), the external integrity of the state territory (war), and the extraction of resources (Krasner 1978; Evans, Rueschemeyer, and Skocpol 1985; Nordlinger 1981; Tilly 1975). Structural Marxism does not treat the state as a mere agent of the ruling class, but grants it an autonomous interest in the long-term maintenance of the capitalist order (Jessop 1982). Theories of bureaucratic politics, finally, clearly state that public actors not only have different interests from private actors but possess a certain autonomy to pursue these interests (Allison 1972; Allison and Halperin 1989). While state-centred approaches bring public actors back in the explanation of state behaviour, they are ambiguous about the nature of the state, that is whether it is an actor or a social institution. ${ }^{7}$

Third, state-society approaches go beyond the dichotomy of statist versus pluralist theories. They concentrate on the institutions of representation, education, and administration that link state and society. Such domestic structure approaches emphasize the different degrees of state strength and autonomy vis-à-vis society. They mainly developed in the field of comparative foreign economic policy in order to explain variations in state responses to similar challenges in the international system (Katzenstein 1976; Katzenstein 1978; Katzenstein 1985; Gourevitch 1986). The notion of domestic structures refers to "the political institutions of the state, to societal structures, and to the policy networks linking the two" (Risse-Kappen 1995a: 20). The central argument is that the political influence of private and public actors depends on the domestic structures of a particular state which mediate, filter, and refract their interests.

Subsystemic approaches privilege private actors in explaining state behaviour. State preferences are ultimately derived from domestic interests, even if they may be mediated by domestic structures. For their predominantly society-centred perspective, they provide the starting point for private-actor based explanations of compliance.

There has been a lively debate in the field of IR which theories, systemic or subsystemic, are superior in analyzing state behaviour in international politics. Proponents of systemic approaches have argued that "liberalism makes sense as an explanatory theory within the constraints pointed out by ... Realism" (Keohane 1990: 192). Systemic theories are held superior because of their parsimony. Subsystemic factors are only acknowledged as intervening variables which introduce residual variance around the preconditions of systemic theory (Waltz 1979; Waltz 1986; Keohane 1986). Advocates of subsystemic approaches object that their explanations enjoy analytical priority because they explain when and why the assumptions about state preferences underlying systemic theories hold, whereas the reverse is not the case (Moravcsik 1997a: 542/543; Moravcsik 1993: 14/15). A third group of scholars

7 For an explication of the conceptual poles 'state as an actor' versus 'state as a social institution' see Skocpol 1985. 
maintains that the emergence of non-state actors in world politics increasingly blurs the distinction between the international and the domestic sphere and, therefore, requires an integrative approach, which systematically combines system-level and sub-system level explanations of state behaviour (Moravcsik 1993; Risse-Kappen 1995a; but see already Deutsch and al. 1957; Haas 1958; Rosenau 1969).

Integrative theories can be divided into two major 'camps'. International bargaining theories conceptualize international negotiations as a two-level game (Putnam 1988; Evans, Jacobson, and Putnam 1993; Moravcsik 1993). Two-level games approaches explain state behaviour as the interplay of powerful socio-economic interests at the domestic level and the bargaining constraints at the international level. The chiefs of government form the crucial link between the two levels. Transnational relations criticize two-level game approaches for ignoring transnational, transgovernmental, and cross-level activities which undercut the gate-keeping position of governments between the domestic and international level. Transnational and transgovernmental alliances are said to limit both the autonomy and the strategy options of state actors in international negotiations (Knopf 1993; Risse-Kappen 1995a; Keck and Sikkink 1998; Risse, Ropp, and Sikkink 1999).

While private actors still feature prominently, integrative theories put private and public actors on a more equal footing. Two-level games approaches assume that state interests cannot be entirely reduced to societal demands. The balancing of international and domestic concerns in a process of "double-edged diplomacy" (Evans, Jacobson, and Putnam 1993) allows state executives to increase their autonomy vis-à-vis their domestic constituencies in pursuing their own interests (Moravcsik 1994; Moravcsik 1997b). Transnational actors undermine the autonomy of national governments in international politics by forming coalitions across national boundaries. But state actors remain one of the major targets of transnational activities (Keck and Sikkink 1998; Risse, Ropp, and Sikkink 1999).

Table 2: Level of Analysis and Privileged Actors

\begin{tabular}{|l|l|}
\hline Level of Analysis & Privileged Actors \\
\hline Systemic Theories & State actors \\
\hline Subsystemic Theories & National private actors \\
\hline Integrative Theories & $\begin{array}{l}\text { (Trans)national private actors } \\
\text { and state actors }\end{array}$ \\
\hline
\end{tabular}

\section{Rationalist versus Constructivist Approaches}

International Relations Theories are embedded in different meta-theories of social action, which lead to different, and sometimes competing, assumptions about (state) behaviour, particularly with respect to the role of institutions. James March and Johan Olsen introduced the distinction between two fundamental modes of social action, the logic of consequentialism 
and the logic of appropriateness (March and Olsen 1989, March and Olsen 1998). ${ }^{8}$ The former is the realm of rational choice approaches that treat the interests and preferences of actors as mostly fixed during the process of interaction. Rational choice focuses on strategic interaction, in which actors engage to maximize their utilities on the basis of given and fixed preferences. They follow a logic of instrumental rationality by weighing the costs and benefits of different strategy options taking into account the (anticipated) behaviour of other actors. Neorealism and Neoliberal Institutionalism are systemic theories which embrace such an instrumental or utilitarian logic of social action. But while Neorealism denies institutions any significant impact on state behaviour, Neoliberal Institutionalism grants them a constraining effect (Krasner 1983a; Krasner 1983b). Self-interested actors establish institutions to prevent their individualistic behaviour from producing collectively suboptimal outcomes, which are worse for all than feasible alternatives under conditions of cooperation (pareto inferior). Institutions, then, set the rules of the game for state interaction. They constrain and facilitate state behaviour, e.g. by providing information or creating transparency without, however, reconfiguring state interests and preferences. International institutions are the creations of states and the servants of their interests. As such, they have no autonomous and causal status. Rationalist approaches are not only found among systemic theories of IR. Liberal theories and some domestic structure approaches are based on the logic of consequentialism, too. Domestic institutions filter, mediate and refract societal interests, but they do not reconfigure them. Consequently, state interests are not really endogenized but imputed "just one more level down below the state level, to individual and groups" (Finnemore 1996: 146).

Constructivist or social structure approaches in IR emphasize the logic of appropriateness as the mode of social action. "Human actors are imagined to follow rules that associate particular identities to particular situations, approaching individual opportunities for action by assessing similarities between current identities and choice dilemmas and more general concepts of self and situations" (March and Olsen 1998: 951). Rule-guided behaviour differs from instrumentally rational behaviour in that actors try "to do the right thing". Rather than maximizing their given interests, actors strive to figure out what would be the appropriate behaviour in a given situation. Stressing the constitutive effect of social norms and institutions, constructivist approaches distance themselves from rationalist approaches by rejecting methodological individualism, which treats actors, their capabilities and preferences as given and derives the social structure from their interaction. ${ }^{9}$ The ontological priority of agent over structure is replaced by the assumption that agency and structure are mutually constitutive. Social structures do not only regulate behaviour but also define the social identities and interests of actors. While individuals do not exist outside social structures, they constantly create, reproduce, and change them. Three strains of social structure-oriented

8 Thomas Risse introduces a third logic of action, the logic of arguing or truth seeking, which allows actors to find out in which situation they are and which norms apply in this situation (Risse 2000). It specifies one causal mechanism through which norms constitute actors and are reproduced by them. Rather than taking it as an entirely separate logic, the logic of arguing could be understood as an integral part of the logic of appropriateness providing it with some mirco-foundations and, thus, bringing agency back in.

9 This applies to the "modernist branch" of constructivism (Checkel 1998), which strives to "seize the middle grounds" between rationalism and post-structuralism, both on ontological and epistemological grounds (Adler 1997). There are more radical strands of constructivism, which challenge the possibility of making truth claims and generalizations in social sciences (Walker 1993; Smith, Booth, and Zalewski 1996). 
approaches can be identified in the IR literature (cf. Finnemore 1996: 15-22). Social constructivism or reflexive institutionalism (Keohane 1989b), which stresses the importance of intersubjective understandings and meanings in structuring the ways in which actors understand what kinds of action are appropriate and necessary. Statist constructivists privilege the state as the major unit of analysis, whose interests are shaped by internationally shared norms and values that structure and give meaning to international politics rather than by external threats or demands by domestic actors. "States are socialized to want certain things by the international society in which they and their people live" (Finnemore 1996: 2; cf. Wendt 1992; Wendt 1996; Wendt 1999; Koslowski and Kratochwil 1995). More societyoriented constructivists stress the importance of (trans)national actors in promoting the internalization of international norms (by state actors) through mobilization, shaming, arguing, and learning (Risse and Sikkink 1999; Keck and Sikkink 1998; Checkel 1997; Checkel 1999a). The English School of Realism shares many assumptions with statist constructivism but treats social structures (international society), in which states are embedded, as coherent and all-encompassing (Wight 1966; Bull 1977), whereas constructivism draws attention to competing and often conflicting norms and values to which states are subject. Sociological Institutionalism, finally, as it has been developed in sociology by John Meyer and his colleagues, maintains that social structure is constituted by an expanding and deepening world culture. The modern international system is governed by a powerful set of world-wide cultural rules, whose core builds the Weberian notion of rationality and which are increasingly internalized by national societies (Meyer, Boli, and Thomas 1987; Meyer and Rowan 1991; Meyer and Scott 1983; Thomas et al. 1987). Like the English School, Sociological Institutionalism views social structure as coherent and allencompassing but it does not treat the international society as a society of states but focuses on a broad variety of actors, ranging from states, over sub-state organizations to individuals.

These rather abstract assumptions about human behaviour and the effect of norms and institutions have significant repercussions for the dominant mechanisms through which compliance with international rules is brought about as well as the ways in which private actors can impact upon compliance with international rules.

The rationalist logic of consequentialism points at the redistribution of resources as the dominant compliance mechanism. International institutions empower actors which favour compliance vis-à-vis those who oppose. States, international organizations, or (trans)national actors obtain resources (e.g. sanctioning power, expertise, money, allies) through which they can constrain the strategy choices of other actors by rendering non-compliance more costly. Consequently, social mobilization and pressure are the major way by which non-state actors influence compliance. Domestic actors, often in transnational alliances with international nongovernmental organizations, exploit international norms and organizations to generate pressure for compliance on public actors. International institutions offer an authoritative venue for private actors to challenge state behaviour. They provide new political opportunities to private actors "encouraging their connections with others like themselves and offering resources that can be used in intra-national and transnational conflict" (Tarrow 2001; cf. Rogowski 1989; Haas 1989; Sikkink 1993; Klotz 1995a; Keck and Sikkink 1998; Risse, Ropp, and Sikkink 1999; Breitmeier and Wolf 1995; Cortell and Davis 1996). By exploiting 
these political opportunities, private actors mobilizing for compliance become empowered vis-à-vis public actors (and private actors opposing compliance). Through pressure "from below and from above" (Brysk 1993), private actors change the cost-benefit calculations of public actors in favour of compliance, essentially by increasing the costs of non-compliance (cf. Börzel 2000b).

The constructivist logic of appropriateness specifies an alternative compliance mechanism, which relies on socialization and habitualization. Through processes of social learning and persuasion, actors internalize new norms and rules of appropriate behaviour and redefine their interests and identities accordingly. Social learning and persuasion are the major ways by which private actors influence compliance. Private actors do not so much constrain public actors' choices by making non-compliance more costly. Rather than merely pressuring actors into compliance, private actors strive to persuade public and private actors, who oppose compliance, to change their interests (Finnemore 1996; Checkel 1999b; Risse, Ropp, and Sikkink 1999). They attempt to engage opponents of compliance in a (public) discourse on why compliance with a particular norm constitutes appropriate behaviour. The appeal to collectively shared norms and identities plays a crucial role in such processes of persuasion (Finnemore and Sikkink 1998: 902). For states e.g., which perceive themselves as modern and liberal, violations of human rights can be framed as seriously contradicting their identity. The same is true for non-compliance with environmental regimes by states that pride themselves as progressive environmental leaders. By engaging addressees and targets in processes of social learning and persuasion, private actors aim at the internalization of an international rule up to the point that it is "taken for granted" (Risse and Sikkink 1999: 5/6).

Integrative approaches do not privilege one compliance mechanism with its respective way of private actors' influence over the other. Differential empowerment and socialization capture and explain different, yet equally important elements of the compliance process (Checkel 1999b; Finnemore and Sikkink 1998; Koh 1997; Keck and Sikkink 1998; Risse 2000). Not only can differential empowerment be as effective as socialization in bringing about compliance with international rules (Checkel 1999b). Social mobilization plays a crucial role in promoting socialization processes (Risse and Sikkink 1999). Yet, there is still little research, which systematically explores the relationship between the two logics of social action. 
Table 3: Logic of Actions, Private Actor Influence, and Dominant Compliance Mechanisms

\begin{tabular}{|l|l|l|}
\hline Logic of Action & $\begin{array}{l}\text { Dominant Compliance } \\
\text { Mechanisms }\end{array}$ & $\begin{array}{l}\text { Source of Private Actor } \\
\text { Influence }\end{array}$ \\
\hline $\begin{array}{l}\text { Rationalist } \\
\text { (consequentialism) }\end{array}$ & $\begin{array}{l}\text { Redistribution of resources } \\
\text { Differential empowerment }\end{array}$ & Pressure, social mobilization \\
\hline $\begin{array}{l}\text { Constructivist } \\
\text { (appropriateness) }\end{array}$ & Socialization and habitualization & Persuasion, social learning \\
\hline $\begin{array}{l}\text { Integrative } \\
\text { (consequentialism/ } \\
\text { appropriateness) }\end{array}$ & $\begin{array}{l}\text { Redistribution of resources and } \\
\text { socialization }\end{array}$ & Pressure and persuasion \\
\hline
\end{tabular}

\subsection{Formulating Hypotheses}

The previous section distinguished major theories in International Relations along the actors they privilege (level of analysis) on one hand, and the dominant compliance mechanism they identify, on the other hand (logic of action). The role of private actors in compliance with international rules varies along these two dimensions. The different combinations of the two dimensions allow to formulate a series of hypotheses about whether and how private actors matter to compliance with international rules.

Table 4: Dominant Compliance Mechanisms and Privileged Actors

\begin{tabular}{|c|c|c|}
\hline $\begin{array}{l}\text { Dominant Compliance Mechanism } \\
\text { Privileged Actors }\end{array}$ & $\begin{array}{l}\text { Redistribution of } \\
\text { Resources }\end{array}$ & Socialization \\
\hline State actors & $\begin{array}{l}\text { Neorealism } \\
\text { Neoliberal Institutionalism } \\
\text { Managed Compliance }\end{array}$ & Statist Constructivism \\
\hline Domestic private actors & $\begin{array}{l}\text { Liberalism } \\
\text { Domestic Structures }\end{array}$ & $\begin{array}{l}\text { Society-centred } \\
\text { Constructivism } \\
\Rightarrow\end{array}$ \\
\hline $\begin{array}{l}\text { State actors and domestic private } \\
\text { actors }\end{array}$ & Two-Level Games & $\begin{array}{l}\text { Sociological } \\
\text { Institutionalism }\end{array}$ \\
\hline Transnational actors & Transnational Liberalism & $\begin{array}{l}\text { Transnational } \\
\text { Constructivism }\end{array}$ \\
\hline
\end{tabular}


Not all compliance theories entirely fit into this scheme, because not only do they combine different levels but also different logics of action (transnational constructivism, domestic structures, managed compliance).

\subsubsection{Misfit as the Pre-Condition for Non-compliance}

While IR approaches differ on the compliance mechanism and the actors they privilege, they share one major assumption, which provides the starting point for this study: Only 'inconvenient' rules, that is rules which impose significant compliance costs (material and immaterial), give rise to compliance problems. Irrespective of the theoretical approach they adhere to, most scholars agree that international norms and rules are most likely to be implemented and complied with, if they fit, i.e. are compatible with the domestic context, such as regulatory standards, political and administrative institutions, problem-solving approaches, and collectively shared identities (Börzel 2000b; Duina 1999; Keohane 1984: 99; Breitmeier and Wolf 1995: 347/348; Underdal 1998: 12; Risse and Ropp 1999: 271; Young 1999: 35; Keck and Sikkink 1998; Cortell and Davis 1996; Checkel 1997; Ulbert 1997b). Another way of approaching the costs of compliance is the (counterfactual) concept of depth of cooperation defined as the degree to which international rules require states to take action which they would not have taken otherwise (Downs, Rocke, and Barsoom 1996; Raustiala and Victor 1998: 662). Analogously, one could argue that the deeper international cooperation, the higher the costs of compliance and the more likely non-compliance becomes.

\section{Hypothesis 1}

State compliance with international rules is the less likely, the less they fit corresponding domestic rules (the deeper the level of international cooperation).

\subsubsection{Compliance Induced by Differential Empowerment}

Rationalist approaches focus on the redistribution of power as the dominant compliance mechanism but differ in their assumptions on which actors are empowered.

\section{Neorealism: Compliance through State Power and Coercion}

Neorealism stresses the anarchic nature of the international system as a result of which states are not only concerned about maximizing their own benefits (wealth, power). They also compare their 'net' benefits against those of their competitor states. States' concern about relative, as opposed to absolute, gains renders agreement on international rules difficult. Moreover, it poses strong incentives for non-compliance. States will only enter an international agreement if it serves their interests (Downs, Rocke, and Barsoom 1996). And they defect as soon as unilateralism promises results which are superior from the perspective of national interests (relative welfare and security). The sole means to deter non-compliance with 'inconvenient' rules are retaliation and rewards by powerful states (Downs, Rocke, and 
Barsoom 1996; Fearon 1998; O'Connell 1992; Baker 1992). Powerful states change the costbenefit calculations of less powerful states by increasing the costs of non-compliance (stick) and lowering the costs of compliance (carrot), respectively.

\section{Hypothesis 2}

State compliance with inconvenient international rules is the more likely, the more a hegemonic state provides positive and negative incentives for compliance.

\section{Neoliberal Institutionalism: Compliance through International Institutions}

Neoliberal institutionalism and functionalist regime theory are less pessimistic than Neorealism about the prospects of international agreements. Because of the "complex interdependence" (Keohane and Nye 1977) between advanced market economies, states do not have to fear the attack of their neighbours and, hence, are more concerned about absolute than relative gains. The pursuit of absolute gains allows states to develop common interests in the realization of joint gains creating strong incentives for international cooperation. Yet, in the absence of a central power able to enforce binding commitments (anarchy), states have a strong incentive for defection (non-compliance). Although their first preference is compliance with a mutually beneficial agreement, the anticipated costs of being cheated by non-compliant states are higher than the benefits of compliance. The rational strategy for states, therefore, is non-compliance. But free riding, i.e. reaping the benefits of an international agreement without complying, only pays as long as (most of the) other states do comply. Otherwise, the agreement breaks down, which is to the detriment of all participants. Thus, states can only realize mutual gains, if they eschew their dominant strategy of non-compliance. International institutions provide a solution to this social dilemma. They constrain strategy choices by prescribing and stabilizing mutual expectations about state behaviour (Stein 1983; Snidal 1985; Keohane 1984; Ostrom 1990). First, institutions specify the expectations on state behaviour, that is define the conditions of compliance. Second, institutions provide information about state behaviour, that is monitor the degree to which states actually comply. Third, institutions allow to coordinate sanctions, that is set the costs of non-compliance. Forth, institutions provide adjudication procedures, that is settle disputes between states over the requirements of compliance. Finally, institutions help to ensure a fair distribution of the gains achieved by an international agreement, that is determine the benefits of compliance (cf. Mitchell 1996; Victor, Raustiala, and Skolnikoff 1998; Legro 1997; Zürn 1997; Gehring 1994; Zangl 1994; Väyrynen 1997; Weitsmann and Schneider 1997; Boyle 1991). In a similar vein, some authors have recently argued that a high degree of legalization of international rules increases the chances of compliance. Legalization is defined in terms of 1) obligation meaning that actors are legally bound by a rule in the sense that their behaviour is subject to scrutiny under general rules, procedures, and discourse of International Law, 2) precision meaning that rules are definite, unambiguously defining the conduct they require, authorize or proscribe, and 3) delegation meaning that authority has been granted to third parties for the 
implementation of the rule, including its interpretation and application, dispute settlement, and further rule-making (Goldstein et al. forthcoming; Abbott et al. forthcoming). ${ }^{10}$

\section{Hypothesis 3}

State compliance with inconvenient international rules is the more likely, the more robust the rules (clarity and density), the more effective the monitoring mechanisms, the more autonomous the international institutions in settling disputes and imposing sanctions, and the fairer the distribution of costs and benefits.

Neoliberal institutionalists, however, go through some great pains in explaining why inconvenient international rules exist in the first place. Why would states agree on an international rule, if it is not beneficial to them? Relaxing the assumption of complete information is the only plausible explanation for the "pathology of non-compliance" (Weiler 1988; Krislov, Ehlermann, and Weiler 1986).

\section{Liberalism: Compliance through Social Mobilization and Pressure}

As Liberalism derives state preferences from domestic interests, pressure from domestic actors with intense distributional concerns explains whether states are likely to comply with international rules (Moravcsik 1997a: 538/539). Inconvenient international rules conflict with state interests because they impose significant compliance costs on powerful domestic actors. As a result, we should expect those actors to mobilize and pressure state actors to refrain from initiating the institutional and policy changes necessary for compliance. The number of domestic veto-players (regions, parties, interest groups, courts) is, hence, crucial for the capacity of states to change the status quo in order to achieve compliance with misfitting international rules (Tsebelis 1995; cf. Scharpf 1988); Alesina and Rosenthal 1995; Wagschal 1999).

\section{Hypothesis 4}

State compliance with inconvenient international rules is the more likely, the lower the number of veto players at the domestic level.

The liberal hypothesis, however, ignores the possibility that a misfitting international rule can empower domestic actors, who strive to change the status quo (Milner 1988; Frieden and Rogowsky 1996; Rogowski 1989). While compliance imposes significant costs on some, others may benefit from the necessary changes. Beside the number of veto-players, their individual preferences should be considered, too. But as Liberalism lacks a theory of societal

10 See also the other contributions to the special issue of International Organization on Legalization and World Politics, forthcoming. 
preference formation, domestic interests cannot be systematically included in a liberal hypotheses on compliance. Moreover, as state preferences are derived from domestic interests, compliance problems should not arise, because states must not subscribe to an international rule which faces powerful domestic opposition in the first place. The divergence between state and domestic preferences on compliance with international rules can only be explained by relaxing the assumption of complete information, which states are supposed to hold on domestic interests. This invites, however, ad hoc explanation of, rather than systematic theorizing about, state compliance (but see below).

\section{Two-Level Games: Compliance through Double-edged Diplomacy}

The ratification of international agreements theoretically links the international and the domestic level in Two-Level Games. The domestic constituents decide whether to ratify and implement the tentative international agreement bargained by their governments in the first stage of the negotiation process. Problems of involuntary defection may arise, when domestic actors override or subvert an international agreement against the opposition of their government (Putnam 1988: 427). Thus, the size of the win-set, defined by the number of agreements, which are likely to be ratified at the domestic level, is crucial for compliance. The size of the win-set depends on three factors: 1) the domestic interests (heterogeneous vs. homogeneous; 2) the political institutions (veto points, autonomy of government); and 3) the strategies of the chief of government (Putnam 1988; cf. Moravcsik 1993; Evans 1993).

\section{Hypothesis 5}

State compliance with inconvenient international rules is the more likely, the larger the domestic win-set (the more homogeneous domestic interests, the fewer veto points, the more autonomous the chief of government, and less the chief of government manipulates the domestic win-set).

Unfortunately, the logic of double-edged diplomacy may support exactly the opposite conclusion. The smaller the size of the domestic win-set, the stronger the bargaining power of the chief of government at the international level (tying hands), the more favourable the international agreement for the domestic constituents, and the more likely is compliance. In other words, heterogeneous domestic interests, a high number of veto points, and little autonomy of the chief of government can increase rather than decrease the likelihood of compliance. The contradiction is at least partly resolved by the first hypothesis of this study. The inconvenience of international rules is a pre-condition for non-compliance. A small domestic win-set should prevent the chief of government to accept any international agreement, which imposes significant costs on her constituents - unless, of course, she pursues a strategy of cutting slack, i.e. tries to expand the domestic win-set to accommodate an international agreement that might be otherwise rejected, e.g. by presenting it as a "take it, or leave it" decision. Yet, while cutting slack may enable national governments to discipline domestic interests in the formal implementation of an international rule, it usually backfires 
when it comes to practical application and rule-consistent behaviour of target actors. Another problem for compliance may arise, if the government does not have sufficient and correct information about the size and nature of the domestic win-set. The problem of incomplete information, however, is captured by the two-level games hypothesis, if it is accepted that the less autonomous a chief of government is, the more informed she will be about the preferences of her constituents.

\section{Transnational Liberalism: Compliance through Pressure from Above and Below}

Transnational actors (TNAs), such as INGOs and MNCs, are actors which operate across national boundaries and do not act on behalf of a national government or an international organization (Keohane and Nye 1971). They influence state compliance with international rules by mobilizing pressure on states from "above", through coalitions with international organizations (monitoring, verification), and from "below", through coalitions with domestic actors. Domestic private actors are not only empowered through information, expertise, moral support, and financial assistance provided by TNAs. TNAs offer them a possibility to circumvent their governments and mobilize support at the international level (Keck and

Sikkink 1998; Risse, Ropp, and Sikkink 1999; Brysk 1993; Klotz 1995b; Börzel 2000b).

\section{Hypothesis 6}

State compliance with inconvenient international rules is the more likely, the more successful pro-compliance transnational networks are in mobilizing pressure from "above" and from "below".

Parts of the transnational relations literature share an implicit normative bias. The influence of TNAs on (inter)national politics is usually portrayed as positive. Transnational advocacy coalitions, epistemic communities, and transnational social movements promote the emergence and diffusion of progressive international norms and rules (human rights, environment, etc.). It is thereby overlooked that TNAs may inhibit rather than facilitate the adoption and implementation of international rules. And economic actors are not always the bad guys. The mobilization of (trans)national NGOs is also responsible for the persistent noncompliance of the European Union with WTO norms on the free trading of genetically modified food.

\subsubsection{Compliance Induced by Socialization}

Constructivist Approaches emphasize socialization and habitualization as the dominant compliance mechanism. They differ, however, in which actors are the major promoters as well as the main targets of the socialization into international rules 


\section{Statist Constructivism: Compliance through State Socialization}

Statist constructivism focuses on collectively shared norms, values, and beliefs, which shape state interests and identities. Compliance is less a conscious decision than the result of a process through which states are socialized into international norms and rules and redefine their interests and identities accordingly. Compliance, then, depends on the successful internalization of international norms and rules up to the point that states take them for granted (Finnemore and Sikkink 1998). ${ }^{11}$ Unfortunately, it is unclear which actors have to be socialized in order to achieve compliance (central decision-makers, bureaucracies, state elites more broadly defined). Nor are the causal mechanisms, through which states get socialized, sufficiently specified. While statist constructivism has reached a high level of sophistication at the meta-theoretical level (Wendt 1999; Kratochwil 1989), its assumptions remain too abstract to guide empirical research. In an attempt to 'put agency back in', some authors stress the importance of international organizations, state leaders, and transnational networks as "teachers" of international norms (Finnemore 1993) or agents of socialization (Finnemore 1996; Finnemore and Sikkink 1998). They argue that state compliance with international norms becomes "contagious" after a critical mass of states (norm leaders) adopted the norms. A "norm cascade" sets in, which is driven by a process of socialization, through which norm leaders persuade other states to adhere. Giving in to peer pressure, other states comply to demonstrate that they conform with the group of states to which they want to belong and whose esteem they care about. The 'compliance pull' (Frank 1990) or norm cascade is reinforced, if the international institution promoting the norm or rule enjoys high legitimacy (Finnemore and Sikkink 1998: 901-905). This is also in line with the argument advanced by legal scholars that a rule may be complied with because it forms part of a legal system which as a whole is deemed legitimate (Dworkin 1986; Hurrell 1995).

\section{Hypothesis 7}

State compliance with inconvenient international rules is the more likely, the more states adhere to them and the higher the legitimacy of the international institutions supporting the rules is, and the more the rule is considered part of a general legal system.

\section{Society-Centred Constructivism: Compliance through Social Learning and Legitimacy}

For Society-Centred Constructivism, domestic rather than state actors have to internalize international norms and rules to achieve compliance. The more international norms and rules resonate or are compatible with pre-existing collective identities and beliefs at the domestic level, the easier is their internalization and the more likely is compliance. This "resonance hypothesis" (Ulbert 1997a; Checkel 1997, 1999b; Cortell and Davis 1996; Jetschke 1999) is already captured by the first hypothesis of this study (misfit as pre-condition for noncompliance). But society-centred constructivism offers another important insight, from which

11 Some studies which draw on socialization approaches do not properly distinguish between norm internalization as the major indicator of compliance (dependent variable) and a process which brings about compliance (independent variable), as a result of which the argument runs the risk of becoming tautological (Zürn and Joerges 1999; Zangl 1999; Risse and Sikkink 1999). 
a fruitful hypothesis about compliance can be derived. It focuses on the socialization of domestic actors into international norms (as their frequent targets) rather than merely on central state decision-makers as statist constructivism does. Through processes of social learning and persuasion, domestic actors internalize new norms and change their beliefs, interests, and behaviour accordingly (Checkel 1999b; Perloff 1993; Risse 2000). Hypotheses about when social learning and persuasion occurs abound. Many authors emphasize the importance of dense interaction facilitated by non-hierarchical (informal) relations (Risse 2000: 19; Rometsch and Wessels 1996; Börzel 1998: 264). At the same time, legal scholars and political scientists argue that deliberative processes, which involve all relevant interests, i.e. the rule addressees and rule targets in rule-making and rule-implementation, significantly increases the legitimacy of the rule motivating voluntary compliance (Frank 1990; Frank 1995; Joerges and Neyer 1997). ${ }^{12}$ Actors do not comply out of fear or self-interest but because they accept a rule on the grounds of its normative rightfulness. Thus, the legitimacy of a rule does not only depend on the participation of all relevant actors so that some interests do not get systematically favoured over others (non-arbitrariness). Next to procedural fairness and justice (cf. Tyler 1997; Lind 1995), legitimacy also results from a process of deliberation, rational discourse or arguing, in which actors justify their claims and challenge those of other actors by appealing to collectively shared norms and values rather than their power or economic interests (bargaining, cf. Steffek 2000; Risse 2000)

\section{Hypothesis 8}

State compliance with inconvenient international rules is the more likely, the more the addressees and the target actors of the rules participate in their formulation, adoption, and implementation, the more rule-making is based on arguing and deliberation (legitimacy), and the denser the interaction between the actors involved (learning).

This hypothesis contradicts to a certain extent the liberal hypothesis as the more actors participate, the more potential veto points.

\section{Sociological Institutionalism: Compliance through Institutional Isomorphism}

Sociological Institutionalism treats the global social structure formed by coherent and allencompassing norms and values (world culture) as the major determinant of state interests and state identities. Because states (as institutions) are located in a similar environment (international system) and are exposed to each other, they develop over time similarities in formal organizational structures, principles of resource allocation, practices, meaning structures, and reform patterns (isomorphism; cf. Meyer and Rowan 1991; DiMaggio and Powell 1991; Scott and Meyer 1994). Like the norm cascade in state constructivism, cultural isomorphism predicts a compliance pull of international norms and values, where it becomes increasingly inappropriate for states and their societies not to adhere. Yet, norm internalization by national societies is not automatic. The institutionalization of international

12 For similar arguments in the field of public policy see Pressman and Wildavsky 1984; Ingram and Schneider 1990; Sabatier 1986. 
norms, i.e. their incorporation into the national legal system, does not equal rule-consistent behaviour in terms of a habitualization and taken-for-grantedness by domestic actors. Institutional decoupling, where individual behaviour does not conform to institutional norms and rules, in which actors are embedded, can deflect the logics of cultural isomorphism (Meyer and Rowan 1991). Institutional decoupling, thereby, points to a major problem for ensuring compliance with international rules. Output (formal and practical implementation) does not automatically lead to the desired outcome (change in behaviour of target actors). Unfortunately, Sociological Institutionalism does not specify conditions under which institutional decoupling is likely to occur nor when and how it is overcome. This is partly due to the neglect of agency, interest, and power (i.e., politics) in the rather structural-determinist logic underlying Sociological Institutionalism. Beside the important insight about the problem of institutional decoupling, Sociological Institutionalism gives rise to a similar hypothesis as statist constructivism:

\section{Hypothesis 9}

State compliance with inconvenient international rules is the more likely, the higher their degree of international institutionalization (giving rise to institutional isomorphism).

\subsubsection{Compliance Induced by Differential Empowerment and Socialization}

\section{Transnational Constructivism: Compliance through Transnational Mobilization}

Transnational Constructivism combines the constructivist compliance mechanism of socialization with the rationalist mechanism of differential empowerment. The major assumption is that sheer pressure (increasing the costs of non-compliance) may be necessary but not sufficient to achieve rule-consistent behaviour in the long run. Transnational pressure can be instrumental to ensure the adoption and institutionalization of international rules (output). Sustainable behaviour changes (outcome), however, require the full internalization of an international rule with actors redefining their interests rather than their strategies only. Changing interests instead of constraining strategies requires social learning, persuasion, and arguing as emphasized by society-centred constructivism. Transnational actors as norm entrepreneurs do not only rely on pressure but use socialization mechanisms to achieve their goals. They engage norm-violators and opponents of compliance in a (public) discourse challenging the appropriateness of their norm-violating behaviour by appealing to collectively shared norms and identities. Such discourses do not only target norm violators (states) as such. They also help to mobilize domestic opposition to pressure from below as well as international organizations and other states to pressure from above (Risse 1999).

\section{Hypothesis 10}

State compliance with inconvenient international rules is the more likely, the more transnational networks manage to engage norm-violators in a reasoned discourse about the (in)appropriateness of their behaviour. 
The "spiral model" of human rights change, developed by Risse, Ropp, and Sikkink, specifies one way in which the two compliance mechanisms may be linked in producing norm implementation and compliance, with pressure being more important in previous stages while persuasion becoming increasingly important toward the latter states of the compliance process (Risse and Sikkink 1999; cf. Finnemore and Sikkink 1998). Checkel, in turn, argues that the more open a political system, the more pressure prevails over learning (Checkel 1999b).

\section{Domestic Structures: Compliance through Domestic Mobilization}

Domestic Structure approaches emphasize that the political influence of private actors depends on the domestic structures of a state. The less access private actors have to the political system, the higher the autonomy of the state vis-à-vis its society (Katzenstein 1978; cf. Kitschelt 1986; Kriesi et al. 1992). But easier access for private actors does not necessarily mean more influence because the coalition-building requirements for reaching a certain policy outcome increase. The easier the political access, the higher the requirements for winning coalitions, and vice-versa (Risse-Kappen 1995a). Thus, the number of veto-players is not sufficient to predict compliance, even if the preferences of private actors are taken into account. Moreover, constructivist-inspired domestic structure approaches argue that the political culture of a state significantly influences the requirements for coalition building. In a strongly decentralized political system, the formation of a winning-coalition may be facilitated by a cooperative political culture, which favours consensus over majority decisions (Katzenstein 1984; Börzel 1999). The capacity of a state to ensure compliance with international rules depends on both its formal and informal institutions.

\section{Hypothesis 11}

State compliance with inconvenient international rules is the more likely, the more domestic actors favouring compliance have access to the implementation process and are able to form winning-coalitions to change the status quo. This will be the more likely, the more open the political system is and the more cooperative its political culture. ${ }^{13}$

\section{"Managed Compliance" and Involuntary Defection: Compliance through Capacity-Building}

Domestic Structure approaches define state capacity to induce compliance in institutional terms. There are, however, alternative conceptions which focus more on socio-economic and administrative capacities of states (Chayes and Chayes Handler 1993; Jänicke 1990; Zürn 1997). Non-compliance is mostly conceived as a problem of "involuntary defection" (Putnam 1988; Chayes and Chayes Handler 1993; Zürn 1997). States do not so much lack the willingness but the capacity, i.e. the necessary resources (technology, expertise,

13 In order to fully explore the domestic structure arguments, one would have to formulate several hypotheses rather than one. Increasing the complexity of the explanation, however, is only justified if more parsimonious approaches fail. 
administrative manpower, financial means, etc.), to comply. Capacity building (financial and technical assistance) rather than sanctioning becomes the primary means to ensure compliance with international rules (Keohane, Haas, and Levy 1993; Marauhn 1996; Mitchell 1996; Underdal 1998; Jänicke 1990; Ponce-Nava 1995).

\section{Hypothesis 12}

State compliance with inconvenient international rules is the more likely, the more resources a state has, and there more resources it receives from the outside to ensure compliance, respectively.

Capacity building forms part of a broader concept of "managed compliance" developed by international lawyers, which - like constructivism - emphasizes persuasion and status (reputation), as opposed to pressure and coercion (sanctions), in inducing compliance (Chayes and Chayes 1991; Chayes and Chayes Handler 1993; Chayes and Chayes Handler 1995). The managed compliance perspective emphasizes the reflexivity of rules, which requires a precise definition of their requirements and a constant review of the rules in light of the experience made in implementation. The role of epistemic communities may be crucial here (Haas 1998; Underdal 1998).

The 12 hypotheses about state compliance do not claim to be encompassing. Nor do they always provide competing explanations. Some of the hypotheses complement rather than supplement each other as they share core assumptions. A combination of say, the three different liberal-rationalist approaches (Liberalism, Two-Level Games, and Transnational Liberalism) is not only possible but probably also necessary to theorize about compliance in its whole complexity. A monocausal explanation of compliance is unlikely do it. Moreover, the explanatory power of the causal mechanisms may vary depending on the nature (voluntary/involuntary non-compliance) and level of non-compliance (formal/practical noncompliance). Yet, to causally weigh the different explanatory factors, it is useful to keep them analytically separate. A quantitative study planned to test the different hypotheses against each other will also allow to recombine them in different ways.

\section{The European Union as a Test Case for Compliance Theories}

Testing the broad range of hypotheses on compliance offered by the literature requires either a research team of about 20 collaborators and 10 years time to complete the study or a large-n study. The latter would be as unfeasible as the former, if it were not for the European Union (EU). The EU is the only institution of 'governance beyond the states' for which comprehensive data on state compliance is available. The annual implementation reports of the Commission give an account of member state infringements of Community Law in the different policy sectors since 1979. Despite some deficiencies, these accounts provide a 
sample of more than 15.000 non-compliance cases spread over a time period of 20 years and comprising nine to 15 member states. There is no such comprehensive data for any international organization. ${ }^{14}$

Obviously, European regulations do not have the same status than other international regulations because of their supranational character. Their supremacy over national regulations as well as their direct effect gives European regulations law character. Unlike international law and regulations, Community Law confers rights to any affected individual to challenge non-compliance with European regulations before national courts. Moreover, the interpretation and application of Community Law is supervised by an independent institution, the European Court of Justice. Finally, the Doctrine of governmental liability empowers national courts to hold a member state liable for damages caused to individuals due to the state's failure to implement European law properly and to require financial compensation. ${ }^{15}$ Yet, despite an elaborate system of judicial review lacked by International Law, I claim that compliance with international and European regulations can be treated following the same approaches. First, the incomparability of compliance with international and European regulations rests on the assumption that legal enforcement capacity (judicial review) is crucial for ensuring compliance with binding regulations. While judicial review may be a the defining characteristics of law distinguishing it from other social norms, it is not the only way nor necessarily the most effective means to achieve compliance (Kratochwil 1983; Frank 1990; Zürn and Wolf 1999; Neyer, Wolf, and Zürn 1999). Moreover, enforcement of Community Law is still largely decentralized as member states are in charge of implementation. The European Union lacks a central administration which is entitled and resourceful enough to directly execute and enforce Community Law. Finally, international and European regulations face similar compliance problems and resemble in the means to address them (Kiss 1996; Zürn and Wolf 1999). The real difference may lie in scope rather than substance.

Second, even if one accepts that supranational regulations are more likely to be complied with than international regulations, the European Union presents a least likely case for noncompliance with non-state regulations. Not only has the EU stronger legal enforcement mechanisms than any international organization. The depth of cooperation in the EU has reached a level that is unpreceded in international politics. Cooperation in the EU does not evolve under conditions of anarchy but is firmly nested within institutions, which severely limit the exit options of individual member states (Gehring 1994). While they can opt out from extensions of European Treaty Law (e.g. opt-out of Denmark and the UK from the Economic and Monetary Union), "every-day decision-making" on issues already subject to the competence of the EU often either precludes a selective opt-out (majority decisions) or renders it prohibitive (interdependence, reputation). The consequences of restricted exit options for compliance are ambiguous. On one hand, institutionalist would argue that strongly institutionalized cooperation renders non-compliance more costly, and hence, less likely. On the other hand, restricted or closed exit decreases the power of voice (Hirschman 1970), that

14 This probably also holds for most states. Thus, none of the EU member states keep records on domestic compliance with state law.

15 ECJ Francovich, C-6 \& 9/90. 
is the possibility of individual member states to veto EU regulations, which they perceive against their interests (Downs, Rocke, and Barsoom 1996). As a result, the EU can be expected to produce significant numbers of 'inconvenient' regulations, which impose significant compliance costs on even powerful member states and are, therefore, likely to cause compliance problems. Selective compliance with Community Law could provide an alternative, de facto exit option (Snyder 1993: 22, but see already Puchala 1975).

Finally, the EU provides the framework for a most similar case design. The similarities of the member states with respect to crucial political and socio-economic features, such as the democracy, rule of law, and market economy, allow to control for some potential explanatory factors by holding them constant, particularly in comparison to authoritarian, repressive regimes or countries in which the state lost its governing capacity (e.g., a minimum capacity to enact and enforce rules, a working civil society, a functioning economy). Moreover, European regulations always enjoy prescriptive status, i.e. their validity is in principle not contested among the member states. This is important, because actors can only violate rules which they accept in the first place. While keeping some basic factors constant, the broad range of European regulations as well as the diversity of the member states (within a basic institutional framework) allows to systematically vary others, such as the type, scope and depth of regulations, their degree of institutionalization, or certain features of domestic structures, such as structures of interest intermediation, degree of territorial decentralization, and political culture.

\section{How to Measure Member State Compliance with Community Law}

\subsection{The EU Infringement Proceedings: Compliance through Negotiation and Adjudication}

The Community Law provides different regulations for dealing with non-compliance with Community Law privileging different actors. First, Article 227 EC Treaty (ex-Article 170) allows member states to bring each other before the ECJ for breaking Community Law. For reasons of 'retaliation', the member states have hardly ever made use of this possibility (Gerichtshof der Europäischen Gemeinschaften 1997). ${ }^{16}$ Second, Article 226 EC Treaty (exArticle 169) grants the European Commission the right to prosecute member states for infringing European legislation. The Commission has increasingly invoked these provisions in her attempt to improve compliance with Community Law (see below). Finally, the doctrine of supremacy ${ }^{17}$ and direct effect $^{18}$ of Community Law permits affected individuals to challenge national regulations in violation with Community Law before national courts. Citizens and corporations have more and more taken advantage of this opportunity (Stone Sweet and Brunell 1998a; Stone Sweet and Brunell 1998b).

16 Occasionally, member states take the opportunity to join in legal action taken by the Commission against another member state in opposition or in support of the defendant.

17 ECJ Costa, C-6/64.

18 ECJ Van Gend en Loos, C-26/62. 
This study focuses on Article 226 actions of the Commission against non-compliant member states because it accounts for the widest variety of cases. Already the Treaty of Paris, which established the European Community of Coal and Steal in 1951, granted the High Authority the right to take action against member states not complying with their legal obligations (Articles 36, 50, and 88 ECSC Treaty). If the High Authority had reasons to believe that a member state violated a treaty obligation, it could send a request asking the member state to submit its observations. If the response of the member state was not satisfactory to the High Authority, it emitted a 'Reasoned Decision' to be executed by the member state to remedy the issue. In case of continued non-compliance, the High Authority could suspend financial payments to the member state or authorize the Council to take countervailing measures. Both types of sanctions, however, required a two-third majority in the Council and were never invoked (Aubenas 1969). ${ }^{19}$ In 1957, the Treaty of Rome judicialized the infringement proceedings strengthening the role of the European Court of Justice (Articles 169-171 EC Treaty). Under the Treaty of Paris, the Court had merely acted as a court of appeal, to which the member states could take Reasoned Decisions of the High Authority for judicial review. Under the new procedure, the European Court of Justice replaced the Commission (High Authority) as the final decision-maker on issues of non-compliance. If the member states do not agree with the Reasoned Opinion (formerly Decision, sic) of the Commission, it is the Commission, which must turn to the ECJ to ultimately decide the issue. ${ }^{20}$

To date, the infringement proceedings of the European Union are regulated by Article 226 EC. Apart from some modifications (see below), they still correspond to the proceedings set up by the Treaty of Rome (Articles 169-171 EC Treaty). Infringement proceedings are opened if the Commission considers that a member state has failed to fulfil a Treaty obligation.

The Commission distinguishes five types of infringements, against which she may take action:

\section{1) Violations of Treaty Provisions, Regulations, and Decisions}

Treaty Provisions, Regulations, and Decisions are directly applicable and, therefore, do not have to be incorporated into national law. ${ }^{21}$ Non-compliance takes the form of not or

19 In fact, during its 17 years of existence, the infringement proceedings of the Treaty of the European Community for Coal and Steal were only invoked 17 times. In only seven cases, a Reasoned Decision was formulated (Aubenas 1969: 461). Yet, the High Authority had an alternative compliance mechanism at hand, of which it made more frequent use: the power to directly impose financial sanctions on individual enterprises which violated their obligations (Articles 49, 50, 60, 64, and 65 ECSC). With the exception of competition law (see also following footnote), the Commission lost her right to directly address non-state actors with the Treaty of Rome.

20 European Competition Law forms an exception because the Commission retains its central infringement powers (Articles 81-84 EC, ex-Articles 85-88). The Commission has both investigative and quasi-judicial powers, which enable her to order breaches of Community Law to be annulled and to impose severe penalties. While the Commission acts both as a prosecutor and a judge, she is subject to the scrutiny of the Court of First Instance, to whom any party subject to Commission decisions can appeal (cf. Chalmers and Szyszczak 1998: 543-577). Due to these special powers of the Commission, competition law should be treated separately.

21 Treaty Provisions and Regulations are generally binding and directly applicable, while Decisions are administrative acts aimed at specific individuals, companies, or governments for which they are binding. 
incorrectly applying and enforcing (see also below) European obligations as well as of taking, or not repealing, violative national measures.

\section{2) Non-transposition of Directives}

Directives are not directly applicable, as a result of which they have to be incorporated into national law. Member states are left the choice as to the form and methods of implementation (within the doctrine of the effet utile, which stipulates that the member states have to choose the most effective means) ${ }^{22}$. Non-compliance manifests itself in a total failure to issue the required national legislation.

\section{3) Incorrect legal implementation of Directives}

The transposition of Directives may be wrongful. Non-compliance takes the form of either incomplete or incorrect incorporation of Directives into national law. Parts of the obligations of the Directive are not enacted or national regulations deviate from European obligations because they are not amended and repealed, respectively.

\section{4) Improper application of Directives}

Even if the legal implementation of a Directive is correct and complete, it still may not be practically applied. Non-compliance involves the active violation of taking conflicting national measures or the passive failure to invoke the obligations of the Directive. The latter also includes failures to effectively enforce Community Law, that is take positive action against violators, both by national administration and judicial organs, as well as make adequate remedies available to the individual against infringements which impinge on her rights.

\section{5) Non-compliance with ECJ judgements}

Once the European Court of Justice finds a member state guilty of infringing Community Law, the member state is finally obliged to remedy the issue. Non-compliance refers to the failure of member states to execute Court judgements, which establish a violation of Community Law. Such cases of "post-litigation non-compliance" (Weiler 1988) are particularly problematic, because the ECJ has hardly any sanctioning and no enforcement powers. Article 7 EUT contains provisions for restricting membership rights. But they only apply if principles are violated on which the European Union is founded such as liberty, democracy, human rights, and the rule of law (Article 6 EUT). The ECJ does not even have the right to declare illegal and suspend a national regulations which it found in violation with Community Law. It can only establish the infringement (cf. Tsikiras 1990: 177).

The non-transposition of Directives is most likely to be detected because the member states are obliged to communicate their transposition measures to the Commission. The noncommunication of measures within the deadline specified by the Directive automatically leads the Commission to take action. Consequently, the data available on total transposition failure is rather reliable. Ironically, the good quality of the data renders them less useful. As transposition failure is easily detected, it accounts for almost $50 \%$ of the infringement

22 ECJ Fédéchar v. High Authority, C-8/55; ECJ Van Gend en Loos, C-26/62. 
proceedings initiated. At the same time, the number of cases drops dramatically as soon as the proceedings reach official status (see below). Only about $5 \%$ are brought before the ECJ. This shows that transposition failure is above all a temporary phenomenon. Of the 1470 Directives in force by December 31, 1998, the member states transposed 98\% (Commission of the European Communities 1999). The variation between the member states as well as between the different policy sectors is marginal.

The incorrect or incomplete transposition of Directives is more difficult to discover because it involves a careful comparison of European and national transposition legislation. To what extent already existing national regulations are sufficient to transpose a Directive and do not need further amendment requires not only an understanding of the legal provisions of the Directive but an interpretation of national legislation which takes into account the legal and administrative practices in the individual member states. As the Commission lacks the administrative capacity to systematically check whether national legislation conforms with European requirements, Article 234 references (formerly Article 177) will be used as an additional indicator for legal/formal non-compliance. Article 234 EC Treaty (ex-Article 177) enables national judges to ask the ECJ to assess the compatibility of European and national legislation. It should be kept in mind, however, that Article 234 EC Treaty references are potentially biased towards member states with legal cultures encouraging both private actors and courts to seek judicial review of Community Law, and resourceful private actors (Conant 2000; Tesoka 1999).

Practical application of Directives, Regulations, Decisions, and Treaty Provisions at the local level is most difficult to reveal. The Commission carries out its own investigations into the execution of Community Law. She maintains numerous contacts, formal and informal, with national implementation authorities, non-governmental organizations, researchers, and corporations. Occasionally, she even sends out inspectors to visit a member state. Nevertheless, given her limited resources, the Commission is largely dependent on external sources of information, such as complaints and petitions.

All in all, the more decentralized the level, where measures are taken to put Community Law into practice, the higher is the number of potential cases of 'unrevealed' non-compliance. This may cause serious problems for the reliability of our data, which will be dealt with further on.

About half of the cases, which the Commission examines because she suspects noncompliance ('suspected infringements'), results from complaints by citizens, corporations, and non-governmental organizations. ${ }^{23}$ The other half is accounted for by petitions to, and questions of, the European Parliament, the Commission's own initiatives (about 15\%), and cases in which member states did not communicate the transposition of a Directive (about $35 \%$ ). The numbers of suspected infringements are published in the Annual Implementation

23 The Commission prepared a standard complaint form (also available on the website of the Commission). It requests details concerning the compliant (kept confidential), the subject-matter of the complaint and possible damage suffered, information on steps taken before national or Community authorities, and documentary or evidence available in support of the complaint. The form also contains a number of administrative safeguards, including that the complainant will be informed of the action taken in response to the complaint. The complaint may be lodged with the Commission in Brussels or any of its information offices in the member states. 
Reports. Yet, suspected infringements are not a reliable indicator for non-compliance because about one third of the cases turns out to be unfounded and gets settled before proceedings are opened. ${ }^{24}$ Moreover, the number of complaints significantly varies between member states depending not only on the activism of the population but also on its sheer number. It is not surprising that the four most populated member states, France, Italy, Spain, and Germany, account for about $50 \%$ of all complaints lodged.

The Commission has developed a series of mechanisms of consultation and negotiation in order to settle issues of suspected infringements before opening formal proceedings. First of all, the Commission informally requests further particulars by the member state. Many of these informal requests are advanced within the Committee of Permanent Representatives of the Member States (COREPER). Moreover, the Directorates General (DG) maintain regular contacts with the competent ministries of the member states. In 1990, the Commission started to institutionalize these contacts. Once or twice a year, members of the legal services of the DGs hold bilateral meetings with their colleagues in the corresponding national ministries. These "packaging meetings" deal with complaints and also seek solutions for established infringements. They are complemented by "Directive Conferences", which are dedicated to the implementation of adopted Directives. In some sectors, additional consultation bodies were established. ${ }^{25}$ After her examinations and her consultations with the member state administration, the Commission takes a decision whether to open an infringement proceedings. The decision is usually made within one year from receipt of the complaint, and the complainant is informed accordingly. The Commission cannot be compelled by a complainant or any other actor to take action under Article 226 against a member state. It is the Commission's discretion, if and when she opens an infringement proceeding and whether and when to move from one stage to the other. ${ }^{26}$

The infringement proceedings consist of three subsequent stages:

\section{The administrative request for compliance (Formal Letter)}

The Formal Letter of the Commission delimits the subject-matter and invites the member state to submit its observations. Member states have between one and two months time to respond, yet, they are not obliged to do so. Formal Letters are not part of the formal proceedings. The Commission considers them as a preliminary stage, which serves the purpose of information and consultation rather than sanctioning (Commission of the European

24 In many cases, the complaints refer to problems not subject to European law.

25 In the sector of environment, e.g., exists the Network for the Implementation and Enforcement of Environmental Law (IMPEL) which represents the highest supervisory bodies of the member states. Moreover, the Forum for Environmental Issues shall facilitate the consultation and exchange of information among the public and private actors involved in the implementation process.

26 ECJ Commission v. Ireland, C-415/85, ECJ Star Fruit Company v. Commission, C-247/87. 
Communities 1984: 4/5). ${ }^{27}$ Formal Letters are only made official, if they refer to cases of nontransposition. Consequently, many formal Letters are not published in the monthly Bulletin and the summary in the General Report of the Commission nor are they supposed to be individually listed in the Annual Implementation reports of the Commission. The total number of Formal Letters sent each year is only provided in aggregate form. Yet, the reports do list Formal Letters which do not relate to non-transposition issues. For political reasons, the Commission sometimes decides to make a Formal Letter public. Moreover, some Directorate Generals are less faithful to the Commission's policy. ${ }^{28}$ Due to the lack of consistency, Formal Letters are a poor indicator for non-compliance.

\section{The formal demand for compliance (Reasoned Opinion)}

The Reasoned Opinion is the first official stage in the infringement proceedings. In her Reasoned Opinion, the Commission gives a detailed account of how she thinks Community Law has been infringed by a member state and states a time-limit, within in which she expects the matter to be rectified. The member states have one month time to respond. Reasoned Opinions are a more reliable indicator for non-compliance because they refer to compliance problems which the member states are not able or willing to solve within a timeframe acceptable to the Commission or they involve issues where a member state rejects the Commission's finding of non-compliance altogether.

\section{The judicial procedures (Referral to the European Court of Justice)}

The ECJ Referral is the last means to which the Commission can resort in cases of persistent non-compliance. ${ }^{29}$ The ECJ acts as the ultimate adjudicator between the Commission and the member states. ${ }^{30}$ First, it verifies whether a member states actually violated European law as claimed by the Commission. Second, it examines whether the European legal act under consideration requires the measures demanded by the Commission. And finally, the Court decides whether to dismiss or grant the legal action of the Commission. If member states

27 But note that, according to the view of the ECJ, the letter defines the object at issue in any subsequent court proceedings. As a result, the Commission is not allowed to include additional points during subsequent stages, even she later discovers new infringements.

28 The aggregate data are drawn from a database administered by the Secretariat General of the Commission, which is also in charge of publishing the Annual Reports. The lists of individual infringement cases, in turn, are provided by the different DGs, as a result of which there are considerable inconsistencies between aggregate and 'raw' data (see below).

29 The previously mentioned bilateral "package meetings" of the Commission with representatives of member state administrations also deal with infringement cases, which the Commission is ready to bring before the ECJ in an attempt to find some last minute solution.

30 Yet, the ECJ does not so much act as a neutral intermediator between the interests of the member states and those of the European Union. Rather, the Court's decisions seem to be oriented towards the development of European standards for the effective implementation, application, and enforcement of European law (Aden 1999). Moreover, the ECJ has instrumentalized its rulings on infringement cases for widening certain Treaty obligations by an integration-friendly interpretation. Such instances of judicial law-making, which are even more prevalent with respect to Article 234 references (ex-Article 177), have been identified as a major source of non-compliance as they constitute positive obligations, in whose elaboration the member states did not participate (Weiler 1988: 347/348). 
refuse to comply with an ECJ judgement, since 1996, the Commission can ask the ECJ to impose financial penalties, either in form of a lump sum or a daily fine, which is calculated according to the scope and duration of the infringement as well as the capabilities of the member states. ${ }^{31}$ Before, however, the Commission has to initiate a new infringement proceeding for post-litigation non-compliance (Article $228 \mathrm{EC}$, ex-Article 171). ECJ trials are time-consuming and may entail significant costs, not only material but also political, because the trials are usually broadly covered by the media, at least in the accused member state. Moreover, in the vast majority of the cases, the ECJ sides with the Commission. ${ }^{32}$ Given the costs and the risks involved, most member states strive to find an agreement with the Commission to settle the issue before the ECJ gives its judgement. As a result, the number of cases which reach the final stage of the infringement proceedings is relatively low and usually involve cases of severe compliance problems. This renders the ECJ Referrals a rather reliable indicator for non-compliance. Yet, the Commission is very careful in pushing member state governments too hard, particularly if they face strong domestic opposition or lack the necessary resources to achieve compliance (Puchala 1975; Mendrinou 1996). There may be a positive bias towards member states with a low political, administrative, and economic capacity being less likely to be brought before the ECJ (see below).

The formal infringement procedures leave wide discretion to the Commission regarding the means to induce state compliance with Community Law, of which the reference to the ECJ is the last resort. Only about 5\% of the infringement cases reach the ECJ. Administrative negotiation clearly prevails over adjudication, although the two work more as complements than alternatives. Thus, the Commission's threat of litigation is an important part of her negotiating strategy. "The main form of dispute settlement used by the Commission is negotiation, and litigation is simply part, sometimes inevitable but nevertheless generally a minor part of this process" (Snyder 1993: 30). In another paper, I will suggest that negotiation and adjudication have distinctive roles in inducing compliance, with the former being more successful in cases of involuntary non-compliance, while the latter being most effective when member states openly defy a European regulation, particularly in cases of deliberate nontransposition.

\subsection{The EU Infringement Proceedings as a Reliable Indicator for (Non)Compliance?}

For any given year, the Annual Reports of the Commission on Monitoring the Application of Community Law provide two types of data. The aggregate data summarize the number of infringement proceedings classified by member state, stage of proceedings (Formal Letter, Reasoned Opinion, ECJ Referral), policy sector, and type of infringement (non-transposition, improper application etc.). The raw data list the individual infringement cases, in which the

31 The basic amount of the fine is multiplied by a factor $n$, taking into account the GDP of a member state and its number of votes in the Council. The " $n$ " for Luxembourg, for instance, is 1 and for Germany 26,4 (OJ C 63, 28.2.1997).

32 This holds particularly true for cases of non-transposition. The ECJ has not been receptive for member state "excuses" such as special circumstances of the domestic legal system (recalcitrant subnational actors, e.g.) or the need to substantially revise national legislation due to policy misfit (Aden 1999). 
Commission took action in the different stages during the year reported. These data, available for the last 20 years, should provide a broad and sound basis for a large-n study on member state compliance with Community Law. The Commission and students of European policymaking alike have grounded their concerns about a growing implementation deficit in the EU on rising numbers of infringement proceedings. Their assumption is that the higher the number of proceedings, the less compliant member states are. Yet, do EU infringement proceedings really qualify as a reliable proxy for (non)compliance? Five issues arise which could question whether the infringement data adequately reflect the scope of member state (non)compliance with Community Law.

\section{1) The problem of unrevealed non-compliance}

Infringement proceedings represent only a small fraction of actual non-compliance with Community Law because they cover only those cases of non-compliance which have been detected by the Commission herself or have been brought to her attention by private and public actors in the member states. While Community data on non-compliance with respect to non-transposition is rather reliable, the level of reliability decreases when it comes to complete and correct legal implementation, practical application and enforcement because those types of infringements are far more difficult to detect. Methodologically, however, the total number of non-compliance cases as an unknown entity only becomes problematic, if infringement cases are systematically biased towards certain member states, policy sectors, or types of infringements, i.e. if non-compliance is more likely to be detected in some member states, policy sectors, or implementation stages than in others. As long as the number of unrevealed cases is either marginal or random, it does not really matter if we do not know the total $\mathrm{n}$ of our sample. In order to find out whether infringement proceedings are systematically biased, we will estimate the actual number of infringements for a sample of member states and policy sectors. In a survey, public, economic, and social actors involved in the different stages of the implementation of European law will be asked to assess the level of compliance in their country with core European regulations in a given policy sector. The countries and policy sectors will be selected by systematically varying the factors, which could potentially bias the distribution of infringement proceedings such as societal activism, the number of institutional veto points, or the level of socio-economic development. ${ }^{33}$ If the relative numbers of infringement proceedings for the selected member states roughly match their (estimated) relative record of (non)compliance in the different policy sectors and implementation stages, we may be still left with only a rough idea about the absolute scope of non-compliance; but at least we can be confident that the infringement proceedings are not biased.

\section{2) Skewed data on revealed non-compliance}

Reporting the aggregate score of the individual member states in the different stages of the infringement proceedings may not be a reliable measure for cases of revealed noncompliance. Each instance, in which a member state was detected infringing a European legal

33 I am indebted to Sonja Wälti for her suggestions on this point. 
act, can be counted up to three times - as a Formal Letter, a Reasoned Opinion, and an ECJ Referral. Such multiple counting considerably skews the data. It may also explain the often strong inconsistencies between the raw and the aggregate data. In 1998, for instance, the Annual Report states that the Commission sent 675 Reasoned Opinions, whereas the list of individual cases only includes 235 Reasoned Opinion (Commission of the European Communities 1999). This study will therefore draw on the raw data. As each individual case will be coded according to its infringement number, those cases can be eliminated, which have been reported several times in different years.

3) Incomplete reporting of revealed non-compliance

Annual Reports provide some aggregate data only for a limited number of years. Thus, the numbers of infringement proceedings against individual member states in the different policy areas are only reported for 1988 through 1992. For the other years, numbers are only published separately either by member state or policy sector. In order to systematically test different explanatory factors for non-compliance, however, we should be able to combine the different categories for which data are provided (i.e. member states, policy sectors, year, types of infringement, stage of proceedings) for the whole period of time considered (1979-99). Fortunately, the raw data report the different categories for each individual infringement case. By coding the individual cases, we arrive at a database where all the categories can be combined as deemed appropriate. Each infringement case reported is coded according to its infringement number, the policy sector it falls into, the infringing member state, the type of infringement, the year when the infringement proceedings were opened, and the current stage in the proceedings.

\section{4) The Problem of Commission discretion}

Another factor which could seriously bias the numbers of infringements against certain member states, policy sectors, or types of infringements is the discretion of the Commission in deciding whether and when to open proceedings and move on to next stage, respectively. The problem is reinforced by the Commission's preference for negotiation over adjudication in settling issues of non-compliance. It has been suggested that the priority of the Commission lies with the timely transposition of Directives (Mendrinou 1996). Moreover, there are some indications that the Commission focuses on cases of voluntary infringement where member states openly defy compliance with European regulations. The Reasoned Opinions probably provide the most reliable indicator for member state compliance. Unlike Formal Letters, they cover cases of more sustained non-compliance, as they could not be settled in preliminary, informal negotiations. At the same time, Reasoned Opinions, unlike ECJ Referrals, are not the ultimo ratio of the Commission in responding to non-compliance. Moreover, the coding of the individual cases provides us with the full history of each infringement case, from its opening through the various stages of the proceedings to its closure. This will allow us to systematically trace potential biases. Finally, given the procedural conceptualization of compliance applied in this study, the different compliance strategies of the Commission are part of the nature of compliance as a negotiated process. 


\section{5) Measuring output rather than outcome}

EU Infringement proceedings are directed against member states. The types of infringements traced and prosecuted by the Commission refer to rule-consistent behaviour of the member states. Consequently, infringements of Community Law under Art. 226 EC Treaty (ex-Article 169) measure output rather than outcome. Outcome is only covered if the member states are also the main targets of a regulation. The rule-consistent behaviour of private actors, to the extent that they are the major targets of a regulation, is only indirectly measured by those cases, in which the member states fail to monitor and enforce European legislation against non-compliant individuals or firms. References to the European Court of Justice by national courts, which provide another quantitative indicator for (non)compliance, also measure output rather than outcome as private actors litigate against states for not complying with Community Law. Hence, rule-consistent behaviour of non-state target actors can only be directly examined by using qualitative methods. While EU infringement proceedings provide a pretty reliable measurement for the output dimension of compliance, they are insufficient for seizing the outcome dimension.

To conclude, EU infringement proceedings can provide a reliable proxy for non-compliance, if raw rather than aggregate data are used. Two caveats still hold, however. First, infringement proceedings measure output rather than outcome. And second, infringement proceedings are of limited use for testing private-actor based explanations, particularly if it turns out that private actors' activities systematically bias the distribution.

\section{Conclusions}

This paper strove to theoretically explore the role of private actors in compliance with international rules. After having clarified the concept of compliance and the distinction between public and private actors, I identified major International Relations theories carrying assumption on state compliance. I distinguished them, first, according to the relative weight they attribute to private actors in compliance, and second, according to the causal mechanisms through which compliance is induced granting private actors different ways for influencing compliance. Taking 'misfit' as a precondition of non-compliance, I derived 11 hypotheses about state compliance with inconvenient international rules, which specify different causal mechanisms through which state actors, international institutions, and private actors, respectively, impact on compliance. These causal mechanisms are neither complete nor necessary mutually exclusive. Rather, they allow to identify and analytically separate causal factors, which may be relevant to explaining state compliance and the respective role of private actors. The final part of the paper discussed the EU as a critical case for testing compliance theories and introduced EU infringement proceedings as a proxy for member state (non)compliance. I argued that, within certain limits, EU infringement proceedings allow for descriptive inferences on state compliance, particularly if analyzed as processes rather than mere outcomes. The nature of the infringement proceedings as processes of negotiation and adjudication corresponds to the procedural understanding of compliance endorsed by this project. 
In the next stage of the project, (some of) the hypotheses will be tested in a large-n study on member state compliance with Community Law. The quantitative study will not only allow me to eliminate some of the (state-centred) hypotheses, reducing the explanatory factors to a number that can be systematically controlled in a comparative study. A multivariate analysis shall enable me to explore potentially combining effects, too, which can then be further explored in the qualitative study. 


\section{Bibliography}

Abbott, Kenneth W., Robert O. Keohane, Andrew Moravcsik, Anne-Marie Slaughter, and Duncan Snidal. forthcoming. The Concept of Legalization. International Organization.

Aden, Hartmut. 1999. Die Umsetzung europäischer Umweltrichtlinien: Kommission und EuGH als Akteure der Implementationskontrolle. Zeitschrift für Rechtssoziologie 20 (2):317-332.

Adler, Emanuel. 1997. Seizing the Middle Ground. Constructivism in World Politics. European Journal of International Relations 3 (3):319-363.

Alesina, Alberto, and Howard Rosenthal. 1995. Partisan Politics. Divided Government, and the Economy. Cambridge: Cambridge University Press.

Allison, Graham. 1972. Essence of Decision. Explaining the Cuban Missile Crisis. Boston: Little, Brown.

Allison, Graham T., and Morton H. Halperin. 1989. Bureaucratic Politics: A Paradigm and Some Policy Implications. In American Foreign Policy: Theoretical Essays, edited by G. J. Ikenberry. Glenview, ILL: Scott, Foresman,

Amin, Samir. 1997. Capitalism in the Age of Globalization. London: Zed Press.

Aubenas, Benoit. 1969. Quelques considerations sur les infraction contre les traités de Paris et de Rome. Revue du Marché Commun (127):458-64.

Baker, Betsy. 1992. Eliciting Non-Party Compliance with Multilateral Environmental Treaties: US Legislation and the Jurisdictional Basis for Compliance Incentives in the Montreal Ozone Protocol. German Yearbook of International Law (35):333-365.

Bernauer, Thomas. 1995. The Effect of Environmental Institutions: How We Might Learn More. International Organization 49 (2):351-377.

Boli, John, and George M. Thomas. 1999. Constructing World Culture. International Nongovernmental Organizations Since 1875. Stanford, CA: Stanford University Press.

Börzel, Tanja A. 1998. Organising Babylon. On the Different Conceptions of Policy Networks. Public Administration 76 (2):253-273.

Börzel, Tanja A. 1999. The Domestic Impact of Europe. Institutional Adaptation in Germany and Spain., Department of Social and Political Science, European University Institute, Florence.

Börzel, Tanja A. 2000a. Positives Regieren jenseits des Nationalstaates und das Problem der "ungewollten Nichtbefolgung". Zur Implementationslogik von EG Regelungen. Manuscript.

Börzel, Tanja A. 2000b. Why there is no Southern Problem. On Environmental Leader and Laggards in the EU. Journal of European Public Policy 7 (1):141-162.

Boyle, Alan. 1991. Saving the World? Implementation and Enforcement of International Law through International Institutions. Journal of Environmental Law (3):229-245. 
Breitmeier, Helmut, and Volker Rittberger. 2000. Environmental NGOs in an Emerging Global Civil Society. In The Global Environment in the Twenty-First Century: Prospects for International Cooperation, edited by P. S. Chasek. Tokyo: United Nations University Press, 130-163.

Breitmeier, Helmut, and Klaus Dieter Wolf. 1995. Analysing Regime Consequences: Conceptual Outlines and Environmental Explanations. In Regime Theory and International Relations, edited by V. Rittberger. Oxford: Clarendon Press, 339-360.

Brysk, Alison. 1993. From Above and From Below: Social Movements, the International System, and Human Rights in Argentina. Comparative Political Studies 26 (3):259285.

Bull, Hedley. 1977. The Anarchical Society: A Study of Order in World Politics. London.

Cardoso, Fernando Henrique, and Enzo Faletto. 1979. Dependency and Development in Latin America. Berkeley, CA: University of California Press.

Chalmers, Damian, and Erika Szyszczak. 1998. European Union Law. Vol. Volume 2. Aldershot: Ashgate.

Chase-Dunn, Christopher. 1989. Global Formation: Structures of the World-economy. Cambridge, MASS: Blackwell.

Chayes, Abram, and Antonia Handler Chayes. 1991. Compliance Without Enforcement: State Behaviour Under Regulatory Treaties. Negotiation Journal 7 (July):311-330.

Chayes, Abram, and Antonia Chayes Handler. 1993. On Compliance. International Organization 47 (2):175-205.

Chayes, Abram, and Antonia Chayes Handler. 1995. The New Sovereignty. Compliance with International Regulatory Agreements. Cambridge, MASS: Harvard University Press.

Checkel, Jeffrey. 1997. International Norms and Domestic Politics: Bridging the RationalistConstructivist Divide. European Journal of International Relations 3 (4):473-495.

Checkel, Jeffery T. 1998. The Constructivist Turn in International Relations Theory. World Politics 50 (2):324-348.

Checkel, Jeffrey T. 1999a. International Institutions and Socialization. ARENA Working Paper (5).

Checkel, Jeffrey T. 1999b. Why Comply? Constructivism, Social Norms and the Study of International Institutions. Oslo: Arena.

Commission of the European Communities. 1984. First Annual Report to the European Parliament on Commission Monitoring of the Application of Community Law - 1983, COM (84) 181 final. Brussels: Commission of the European Communities.

Commission of the European Communities. 1999. Sixteenth Annual Report on Monitoring the Application of Community Law (1998), COM (99) 301 final. Vol. COM (99) 301 final. Brussels: Commission of the European Communities. 
Conant, Lisa Joy. 2000. Europeanization and the Courts: Variable Patterns of Adaptation among National Judiciaries. In Europeanization and Domestic Change, edited by M. G. Cowles, J. A. Caporaso and T. Risse. Ithaca, NY: Cornell,

Cook, Helena. 1996. Amnesty International at the United Nations. In The Conscience of the World. The Influence of Non-Governmental Organisations in the UN System, edited by P. Willets. London: Hurst \& Company, 181-213.

Cortell, Andrew P., and James W. Jr. Davis. 1996. How do International Institutions Matter? The Domestic Impact of International Rules and Norms. International Studies Quarterly 40:451-478.

Cutler, Claire A., Virginia Haufler, and Tony Porter, eds. 1999. Private Authority and International Affairs. Albany: State University of New York.

Czempiel, Ernst-Otto. 1999. Kluge Macht: Außenpolitik für das 21. Jahrhundert. München: Beck.

Dahl, Robert. 1961. Who Governs: Democracy and Power in an American City. New Haven, CT: Yale University Press.

Deutch, John. 1997. Terrorism. Foreign Policy 108:10-XX.

Deutsch, Karl W., and et al. 1957. Political Community and the North Atlantic Area: International Organization in the Light of Historical Experience. Princeton, NJ: Princeton University Press.

DiMaggio, Paul J., and Walter W. Powell. 1991. The Iron Cage Revisited: Institutional Isomorphism and Collective Rationality in Organizational Fields. In The New Institutionalism in Organizational Analysis, edited by W. W. Powell and P. J. DiMaggio. Chicago, London: University of Chicago Press, 63-82.

Downs, George W., David M. Rocke, and Peter N. Barsoom. 1996. Is the Good News About Compliance Good News About Cooperation? International Organization 50 (3):379406.

Drucker, Peter F. 1997. The Global Economy and the Nation-State. Foreign Affairs 76 (5):159-XX.

Duina, Francesco G. 1999. Harmonizing Europe. Nation-States within the Common Market. New York: State University of New York Press.

Dworkin, Ronald. 1986. Law's Empire. Cambridge, MA: MIT Press.

Easton, David. 1965. A Systems Analysis of Political Life. New York: Wiley \& Sons.

Evans, Peter, Dietrich Rueschemeyer, and Theda Skocpol, eds. 1985. Bringing the State Back In. Cambridge: Cambridge University Press.

Evans, Peter B. 1993. Building an Integrative Approach to International and Domestic Politics. In Double-Edged Diplomacy. International Bargaining and Domestic Politics, edited by P. B. Evans, H. K. Jacobsen and R. D. Putnam. Berkeley, CA: University of California Press, 397-430. 
Evans, Peter B., Harold K. Jacobson, and Robert D. Putnam, eds. 1993. Double-Edged Diplomacy: International Bargaining and Domestic Politics. Berkeley CA: University of California Press.

Fearon, James. 1998. Bargaining, Enforcement, and International Cooperation. International Organization 52 (2):269-305.

Finnemore, Martha. 1993. International Organization as Teachers of Norms: The United Nations Educational, Scientific, and Cultural Organization and Science Policy. International Organization 47 (4):565-597.

Finnemore, Martha. 1996. National Interests in International Society. Ithaca: Cornell University Press.

Finnemore, Martha, and Kathryn Sikkink. 1998. International Norm Dynamics and Political Change. International Organization 52 (4):887-917.

Frank, André Gunder. 1969. Capitalism and Underdevelopment in Latin America: Historical Studies of Chile and Brazil. New York: Monthly Review Press.

Frank, Thomas. 1990. The Power of Legitimacy Among Nations. ???: ???

Frank, Thomas. 1995. Fairness in International Law and Institutions. Oxford: Clarendon Press.

Frieden, Jeffry A., and Ronald Rogowsky. 1996. The Impact of the International Economy on National Policies: An Analytical Overview. In Internationalization and Domestic Politics, edited by R. O. Keohane and H. V. Milner. Cambridge: Cambridge University Press, 25-47.

Gehring, Thomas. 1994. Der Beitrag von Institutionen zur Förderung der internationalen Zusammenarbeit. Zeitschrift für Internationale Beziehungen 1 (2):211-242.

Gerichtshof der Europäischen Gemeinschaften. 1997. Jahresbericht 1997. Luxemburg: Gerichtshof der Europäischen Gemeinschaften.

Goldstein, Judith, Miles Kahler, Robert O. Keohane, and Anne-Marie Slaughter. forthcoming. Introduction: Legalization and World Politics. International Organization.

Gourevitch, Peter A. 1986. Politics in Hard Times: Comparative Responses to International Economic Crisis. Ithaca: Cornell University Press.

Grieco, Joseph M. 1988. Anarchy and the limits of cooperation: a realist critique of the newest liberal institutionalism. International Organization 42 (3):485-507.

Haas, Ernst B. 1958. The Uniting of Europe: Political, Social, and Economic Forces 19501957. Stanford, CA: Stanford University Press.

Haas, Peter M. 1989. Do Regimes Matter? Epistemic Communities and Mediterranean Pollution Control. International Organization 43:377-403.

Haas, Peter M. 1992. Introduction: Epistemic Communities and International Policy Coordination. International Organization 46 (1):1-36. 
Haas, Peter M. 1998. Compliance with EU Directives: Insights from International Relations and Comparative Politics. Journal of European Public Policy 5 (1):17-37.

Haufler, Virginia. 1995. Crossing the Boundary between Public and Private: International Regimes and Non-State Actors. In Regime Theory and International Relations, edited by V. Rittberger. Oxford: Clarendon Press, 94-111.

Hirschman, Albert O. 1970. Exit, Voice, and Loyalty. Responses to the Decline in Firms, Organizations, and States. Cambridge, MA: Harvard University Press.

Hirst, Paul, and Graham Thompson. 1996. Globalization in Question. The International Economy and the Possibilities of Governance. Cambridge: Polity Press.

Hurrell, Andrew. 1995. International Society and the Study of Regimes. A Reflective Approach. In Regime Theory and International Relations, edited by V. Rittberger. Oxford: Clarendon Press, 49-72.

Ingram, Helen, and Anne Schneider. 1990. Improving Implementation Through Framing Smarter Statutes. Journal of Public Policy 10 (1):67-88.

Jacobsen, Harold K., and Edith Weiss Brown. 1995. Strengthening Compliance with International Environmental Accords: Preliminary Observations from a Collaborative Project. Global Governance 1 (2):119-148.

Jänicke, Martin. 1990. Erfolgsbedingungen von Umweltpolitik im international Vergleich. Zeitschrift für Umweltpolitik 3:213-232.

Jervis, Robert. 1976. Perception and Misperception in International Politics. Princeton, NJ: Princeton University Press.

Jessop, Bob. 1982. The Capitalist State: Marxist Theories and Methods. New York: New York University Press.

Jetschke, Anja. 1999. Linking the Unlinkable? International Norms and Nationalism in Indonesia and the Philippines. In The Power of Human Rights: International Norms and Domestic Change, edited by T. Risse, K. Sikkink and S. C. Ropp. Cambridge: Cambridge University Press, 134-171.

Joerges, Christian, and Jürgen Neyer. 1997. From Intergovernmental Bargaining to Deliberative Political Processes: The Constitutionalisation of Comitology. European Law Journal 3 (3):273-299.

Katzenstein, Peter J. 1976. International Relations and Domestic Structures: Foreign Economic Policies of Advanced Industrial States. International Organization 30 (1):145.

Katzenstein, Peter J., ed. 1978. Between Power and Plenty: Foreign Economic Policies of Advanced Industrial States. Madison: Wisconsin University Press.

Katzenstein, Peter J. 1984. Corporatism and Change. Austria, Switzerland, and the Politics of Industry. Ithaca and London: Cornell University Press.

Katzenstein, Peter J. 1985. Small States in World Market. Industrial Policy in Europe. Ithaca and London: Cornell University Press. 
Katzenstein, Peter J. 1996. Cultural Norms and National Security: Police and Military in Post-War Japan. Ithaca, NY: Cornell University Press.

Keck, Margaret, and Kathryn Sikkink. 1998. Activists Beyond Borders: Advocacy Networks in International Politics. Ithaca NY: Cornell University Press.

Keohane, Robert O. 1984. After Hegemony. Cooperation and Discord in the World Political Economy. Princeton, NJ: Princeton University Press.

Keohane, Robert O. 1986. Theory of World Politics: Structural Realism and Beyond. In NeoRealism and its Critics, edited by R. O. Keohane. New York: Columbia University Press, 158-203.

Keohane, Robert O. 1989a. International Institutions and State Power. Boulder, CO: Westview.

Keohane, Robert O. 1989b. International Institutions: Two Approaches. In International Institutions and State Power, edited by R. O. Keohane. Boulder, CO: Westview, 158179.

Keohane, Robert O. 1990. International Liberalism Reconsidered. In The Economic Limits to Modern Politics, edited by J. Dunn. Cambridge: Cambridge University Press, 165194.

Keohane, Robert O. 1995. The Analysis of International Regimes. Towards a EuropeanAmerican Research Programme. In Regime Theory and International Relations, edited by V. Rittberger. Oxford: Clarendon Press, 23-45.

Keohane, Robert O., Peter M. Haas, and Marc A. Levy. 1993. The Effectiveness of International Environmental Institutions. In Institutions for the Earth. Sources of Effective International Environmental Protection, edited by P. M. Haas, R. O. Keohane and M. A. Levy. Cambridge, MA: MIT Press, 3-26.

Keohane, Robert O., and Joseph S. Jr. Nye, eds. 1971. Transnational Relations and World Politics. Cambridge, MA: Harvard University Press.

Keohane, Robert O., and Jospeh S. Jr. Nye. 1977. Power and Interdependence. Boston, MASS: Little, Brown.

Kiss, Alexandre-Charles. 1996. Compliance with International and European Environmental Obligations. Hague Yearbook of International Law (9):45-54.

Kitschelt, Herbert P. 1986. Political Opportunity Structures and Political Protest: AntiNuclear Movements in Four Democracies. British Journal of Political Science 16:5785.

Klotz, Audie. 1995a. Norms in International Relations. The Struggle against Apartheid. Ithaca, NY: Cornell University Press.

Klotz, Audi. 1995b. Norms Reconstituting Interests: Global Racial Equity and U.S. Sanctions Against South Africa. International Organization 49:???? 
Knopf, Jeffrey W. 1993. Beyond Two-Level Games: Domestic-International Interaction in the Intermediate-Range Nuclear Forces Negotiations. International Organization 47 (4):599-628.

Koh, Harold Hongju. 1997. Why Do Nations Obey International Law? The Yale Law Journal 106:2599-2659.

Korey, William. 1998. NGOs and the Universal Declaration of Human Rights. "A Curious Grapevine". New York: St. Martin's Press.

Koslowski, Rey, and Friedrich Kratochwil. 1995. Understanding Change in International Politics. The Soviet Empire's Demise and the International System. In International Relations Theory and the End of the Cold War, edited by R. N. Lebow and T. RisseKappen. New York: Columbia University Press, 127-165.

Krasner, Stephen. 1978. Defending the National Interest: Raw Material Investment and US Foreign Policy. Princeton, NJ: Princeton University Press.

Krasner, Stephen D. 1983a. Regimes and the Limits of Realism: Regimes as Autonomous Variables. In International Regimes, edited by S. D. Krasner. Ithaca, NY: Cornell University Press, 355-368.

Krasner, Stephen D. 1983b. Structural Causes and Regime Consequences: Regimes as Intervening Variables. In International Regimes, edited by S. D. Krasner. Ithaca, NY: Cornell University Press, 1-21.

Kratochwil, Friedrich. 1989. Rules, Norms, and Decisions. Cambridge: Cambridge University Press.

Kratochwil, Friedrich. 1995. Contract and Regimes: Do Issue Specificity and Variations of Formality Matter? In Regime Theory and International Relations, edited by V. Rittberger. Oxford: Clarendon Press, 73-93.

Kratochwil, Friedrich V. 1983. Is International Law "Proper" Law? The Concept of Law in the Light of an Assessment of the "Legal" Nature of Prescriptions in the International Arena. Archiv für Rechts- und Sozialphilosophie 69 (1):13-46.

Kriesi, Hanspeter, Ruud Koopmans, Jan Willem Duyvendak, and Giugni, Marco G. 1992. New Social Movements and Political Opportunities in Western Europe. European Journal of Political Research 22:219-244.

Krislov, S, Claus-Dieter Ehlermann, and Jospeh Weiler. 1986. The Political Organs and the Decision-Making Process in the United States and the European Community. In Integration Through Law, Methods, Tools and Institutions: Political Organs, Integration Techniques and Judicial Process, edited by M. Cappelletti, M. Seccombe and J. Weiler. Berlin: Gruyter, 3-112.

Legro, Jeffrey W. 1997. Which Norms Matter? Revisiting the 'Failure' of Internationalism. International Organization 51 (1):31-63.

Levy, Marc A., Oran R. Young, and Michael Zürn. 1995. The Study of International Regimes. European Journal of International Relations 1 (3):267-330. 
Lind, E. Allan. 1995. Verfahrensgerechtigkeit und Akzeptanz rechtlicher Autorität. In Verfahrensgerechtigkeit. Rechtspsychologische Forschungsbeiträge für die Justizpraxis, edited by G. Bierbauer, W. Gottwald and -. S. Birnbreier, Beatrix. Köln, 3-19.

Marauhn, Thilo. 1996. Towards a Procedural Law of Compliance Control in International Environmental Relations. Zeitschrift für Ausländisches Öffentliches Recht und Völkerrecht 56 (2):686-731.

March, James G., and Johan P. Olsen. 1989. Rediscovering Institutions. New York: The Free Press.

March, James G., and Johan P. Olsen. 1998. The Institutional Dynamics of International Political Orders. International Organization 52 (4):943-969.

Mayntz, Renate, ed. 1983. Implementation politischer Programme II. Opladen: Westdeutscher Verlag.

Mearsheimer, John. 1994/95. The False Promise of International Institutions. International Security 19 (3):5-49.

Mendrinou, Maria. 1996. Non-Compliance and the European Commission's Role in Integration. Journal of European Public Policy 3 (1):1-22.

Meyer, John W., John Boli, and George Thomas. 1987. Ontology and Rationalization in the Western Cultural Account. In Institutional Structure: Constituting State, Society, and the Individual, edited by G. Thomas and e. al. Newbury Park CA: Sage, 12-37.

Meyer, John W., and Brian Rowan. 1991. Institutional Organizations: Formal Structure as Myth and Ceremony. In The New Institutionalism in Organizational Analysis, edited by W. W. Powelll and P. J. DiMaggio. Chicago and London: University of Chicago Press, 41-62.

Meyer, John W., and W. R. Scott. 1983. Organizational Environments: Ritual and Rationality. Beverly Hills, CA: Sage.

Mills, C. Wright. 1956. The Power Elite. New York: Oxford University Press.

Milner, Helen V. 1988. Resisting Protectionism: Global Industries and the Politics of International Trade. Princeton: Princeton University Press.

Mitchell, Ronald B. 1996. Compliance Theory: An Overview. In Improving Compliance with International Environmental Law, edited by J. Cameron, J. Werksman and P. Roderick. London: Earthscan, 3-28.

Moravcsik, Andrew. 1993. Introduction: Integrating International and Domestic Theories of International Bargaining. In Double-Edged Diplomacy: International Bargaining and Domestic Politics, edited by P. B. Evans and e. al. Berkeley CA: University of California Press, 3-42.

Moravcsik, Andrew. 1994. Why the European Community Strengthens the State: Domestic Politics and International Cooperation. Cambridge, Mass.: Harvard University. 
Moravcsik, Andrew. 1997a. Taking Preferences Seriously.: A Liberal Theory of International Politics. International Organization 51 (4):513-553.

Moravcsik, Andrew. 1997b. Warum die Europäische Union die Exekutive stärkt: Innenpolitik und internationale Kooperation. In Projekt Europa im Übergang? Staat und Demokratie in der Europäischen Union, edited by K. D. Wolf. Baden-Baden: Nomos, 211-269.

Müller, Harald. 1993. Die Chance der Kooperation. Darmstadt: Wissenschaftliche Buchgesellschaft.

Neyer, Jürgen, Dieter Wolf, and Michael Zürn. 1999. Recht jenseits des Staates. Bremen: Zentrum für europäische Rechtspolitik.

Nollkämper, André. 1992. On the Effectiveness of International Rules. Acta Politica 27 (1):49-70.

Nordlinger, Eric a. 1981. On the Autonomy of the Democratic State. Cambridge: Cambridge University Press.

O'Connell, Mary Ellen. 1992. Enforcing the New International Law of the Environment. German Yearbook of International Law (35):293-332.

Omahe, Kenichi. 1990. The Borderless World. Power and Strategy in an Interlinked Economy. New York: Harper.

Ostrom, Eleonor. 1990. Governing the Commons. The Evolution of Institutions for Collective Action. Cambridge: Cambridge University Press.

Oye, Kenneth, ed. 1986. Cooperation under Anarchy. Princeton, NJ.: Princeton Uni-versity Press.

Perloff, Richard. 1993. The Dynamics of Persuasion. Hillsdale, NJ: Erlbaum Associates.

Ponce-Nava, Diana. 1995. Capacity Building in Environmental Law and Sustainable Development. In Sustainable Development and International Law, edited by W. Lang. London: ????, 131-136.

Pressman, J., and Aaron Wildavsky. 1984. Implementation. 2nd ed. Berkeley, CA: University of California Press.

Puchala, Donald J. 1975. Domestic Politics and Regional Harmonization in the European Communities. World Politics 27 (4):496-520.

Putnam, Robert. 1988. Diplomacy and Domestic Politics. The Logic of Two-Level Games. International Organization 42 (2):427-460.

Raustiala, Kal, and David G. Victor. 1998. Conclusions. In The Implementation and Effectiveness of International Environmental Commitments: Theory and Practice, edited by D. G. Victor, K. Raustiala and E. B. Skolnikoff. Cambridge, MA: MIT Press, 659-707.

Reinicke, Wolfgang H. 1998. Global Public Policy. Governing without Government? Washington, D.C.: Brookings. 
Ridgeway, J. 1995. Blood in the Face: The Ku Klux Klan, Aryan Nations, Nazi Skinheads, and the Rise of a New White Culture. 2nd ed. New York: Thunder's Mouth Press.

Risse, Thomas. 1999. International Norms and Domestic Change. Arguing and Strategic Adaptation in the Human Rights Area. Politics and Society 27 (4):526-556.

Risse, Thomas. 2000. Let's Argue. Communicative Action in International Relations. International Organization 54 (1):1-39.

Risse, Thomas, and Stephen C. Ropp. 1999. Conclusions. In The Power of Human Rights. International Norms and Domestic Change, edited by T. Risse, S. C. Ropp and K. Sikkink. Cambridge: Cambridge University Press, 234-278.

Risse, Thomas, Stephen C. Ropp, and Kathryn Sikkink, eds. 1999. The Power of Human Rights. International Norms and Domestic Change. Cambridge: Cambridge University Press.

Risse, Thomas, and Kathryn Sikkink. 1999. The Socialization of International Human Rights Norms Into Domestic Practices: Introduction. In The Power of Human Rights. International Norms and Domestic Change, edited by T. Risse, S. C. Ropp and K. Sikkink. Cambridge: Cambridge University Press, 1-38.

Risse-Kappen, Thomas. 1995a. Bringing Transnational Relations Back In: Introduction. In Bringing Transnational Relations Back In. Non-State Actors, Domestic Structures and International Institutions, edited by $\mathrm{T}$. Risse-Kappen. Cambridge: Cambridge University Press, 3-33.

Risse-Kappen, Thomas. 1995b. Democratic Peace - Warlike Democracies? A Social Constructivist Interpretation of the Liberal Argument. In Special Issue of European Journal of International Relations, edited by N. P. Gleditsch and T. Risse-Kappen, 489-515.

Rittberger, Volker, ed. 1995a. Regime Theory and International Relations. Oxford: Clarendon Press.

Rittberger, Volker. 1995b. Research on Regimes in Germany: The Adaptive Internalization of an American Social Science Concept. In Regime Theory and International Relations, edited by V. Rittberger. Oxford: Clarendon Press, 3-22.

Rogowski, Ronald. 1989. Commerce and Coalitions: How Trade Affects Domestic Political Alignments. Princeton, NJ: Princeton University Press.

Rometsch, Dietrich, and Wolfgang Wessels. 1996. The European Union and the Member States: Towards Institutional Fusion? Manchester and New York: Manchester University Press.

Rosenau, James N. 1969. Linkage Politics: Essays on the Convergence of National and International Systems. New York: Free Press.

Sabatier, Paul A. 1986. Top-Down and Bottom-up Approaches to Implementation Research. Journal of Public Policy 6:21-48. 
Scharpf, Fritz W. 1988. The Joint-Decision Trap: Lessons from German Federalism and European Integration. Public Administration 66:239-278.

Scott, W. R., and J. W. Meyer. 1994. Institutional Environments and Organizations. Thousand Oaks, CA: Sage.

Sikkink, Kathryn. 1993. Human Rights, Principled Issue Networks, and Sovereignty in Latin America. International Organization 47 (3):411-441.

Singer, David J. 1960. International Conflict: Three Levels of Analysis. World Politics 12:453-461.

Singer, David J. 1961. The Level-of -Analysis Problem in International Relations. World Politics 14:77-92.

Skocpol, Theda. 1985. Bringing the State Back In: Strategies of Analysis in Current Research. In Bringing the State Back In, edited by P. B. Evans, D. Rueschenmeyer and T. Skocpol. Cambridge: Cambridge University Press, 3-37.

Smith, Jackie. 1997. Building Political Will after UNCED: Earth Action International. In Transnational Social Movements and Global Politics. Solidarity Beyond the State, edited by J. Smith, C. Chatfield and R. Pagnucco. Syracuse, NY: Syracuse University Press, 175-191.

Smith, Jackie, Charles Chatfield, and Ron Pagnucco, eds. 1997. Transnational Social Movements and Global Politics: Solidarity Beyond the State. Syracuse, NY: Syracuse University Press.

Smith, Steve, Ken Booth, and Marysia Zalewski, eds. 1996. International Theory. Positivism and Beyond. Cambridge: Cambridge University Press.

Snidal, Duncan. 1985. Coordination versus Prisoners' Dilemma: Implications for International Cooperation and Regimes. American Political Science Review 79 (4):205-239.

Snyder, Francis. 1993. The Effectiveness of European Community Law. Institutions, Processes, Tools and Techniques. Modern Law Review (56):19-54.

Steffek, Jens. 2000. The Power of Rational Discourse and the Legitimacy of International Governance. Florence: European University Institute.

Stein, Arthur A. 1983. Coordination and Collaboration: Regimes in an Anarchic World. In International Regimes, edited by S. D. Krasner. Ithaca, NY: Cornell University Press, 115-140.

Stone Sweet, Alec, and Thomas Brunell. 1998a. The European Court and the National Courts: A Statistical Analysis of Preliminary References, 1961-95. Journal of European Public Policy.

Stone Sweet, Alec, and Thomas L. Brunell. 1998b. Constructing a Supranational Constitution: Dispute Resolution and Governance in the European Community. American Political Science Review 92 (1):63-81.

Strange, Susan. 1996. The Retreat of the State. The Diffusion of Power in the World Economy. Cambridge: Cambridge University Press. 
Tarrow, Sidney. 2001. Beyond Globalization: Why Creating Transnational Social Movements is so Hard and When is it Most Likely to Happen? Annual Review of Political Science 5.

Tesoka, Sabrina. 1999. Judicial Politics in the European Union: Its Impact on National Opportunity Structures for Gender Equality. Köln: Max-Planck-Institut für Gesellschaftsforschung.

Thomas, George M., John W. Meyer, Francisco Ramirez, and John Boli, eds. 1987. Institutional Structure: Constituting State, Society, and the Individual. Newbury Park, CA: Sage.

Tilly, Charles. 1975. The Formation of the Nation State. Princeton, NJ: Princeton University Press.

Tsebelis, George. 1995. Decision Making in Political Systems. Veto Players in Presidentialism, Parliamentarism, Multicameralism and Multipartism. British Journal of Political Science (25):289-325.

Tsikiras, Dimitrios. 1990. Die Wirkung der Urteile des Europäischen Gerichtshofs im Vertragsverletzungsverfahren (Art. 169 ff. EWGV). Berlin: Duncker \& Humblot.

Tyler, Tom R. 1997. Procedural Fairness and Compliance with the Law. Schweizerische Zeitschrift für Volkswirtschaft und Statistik 133 (2/2):219-240.

Ulbert, Cornelia. 1997a. Die Konstruktion von Umwelt. Der Einfluss von Ideen, Institutionen und Kultur auf (inter-)nationale Klimapolitik in den USA und der Bundesrepublik Deutschland. Baden-Baden: Nomos.

Ulbert, Cornelia. 1997b. Ideen, Institutionen und Kultur. Die Konstruktion (inter-)nationaler Klimapolitik in der BRD und in den USA. Zeitschrift für Internationale Beziehungen 4 (1):9-40.

Underdal, Arild. 1998. Explaining Compliance and Defection: Three Models. European Journal of International Relations 4 (1):5-30.

Väyrynen, Raimo. 1997. International Stability and Risky States: The Enforcement of Norms. In Enforcing Cooperation. Risky States and International Management of Conflict, edited by G. Schneider and P. Weitsmann. Basingstoke: Macmillan, 37-59.

Victor, David G., Kal Raustiala, and Eugene B. Skolnikoff, eds. 1998. The Implementation and Effectiveness of International Environmental Commitments. Cambridge, MA: MIT Press.

Wagschal, Uwe. 1999. Schranken staatlicher Steuerungspolitik: Warum Steuerreformen scheitern können. In Nationaler Staat und internationale Wirtschaft, edited by A. Busch and T. Plümper. Baden-Baden: Nomos, 223-248.

Walker, R.B.J. 1993. Inside/Outside: International Relations as Political Theory. Cambridge: Cambridge University Press.

Wallerstein, Immanuel. 1974. The Modern World-System. Vol. 1. New York: Academic Press. 
Waltz, Kenneth. 1979. Theory of International Politics. Reading, Mass.: Addison-Wesley.

Waltz, Kenneth. 1986. Reflections on Theory of International Politics: A Response to My Critics. In Neorealism and Its Critics, edited by R. Keohane. New York: Columbia University Press, 322-345.

Waltz, Kenneth N. 1959. Man, the State, and War: A Theoretical Analysis. New York: Columbia University Press.

Wapner, Paul. 2000. The Transnational Politics of Environmental NGOs: Governmental, Economic, and Social Activism. In The Global Environment in the Twenty-First Century: Prospects for International Cooperation, edited by P. S. Chasek. Tokyo: United Nations University, 87- 108.

Weiler, Joseph. 1988. The White Paper and the Application of Community Law. In 1992: One European Market?, edited by R. Bieber, R. Dehousse, J. Pinder and J. H. H. Weiler. Baden-Baden: Nomos, 337-358.

Weiss, T. G., and L. Gordenker, eds. 1996. NGOs, the UN and Global Governance. Boulder, CO: Lynne Rienner.

Weitsmann, Patricia A., and Gerald Schneider. 1997. Risky States: Implications for Theory and Policy Making. In Enforcing Cooperation. Risky States and Intergovernmental Management of Conflict, edited by G. Schneider and P. A. Weitsmann. London: Macmillan, 283-294.

Wendt, Alexander. 1992. Anarchy is what states make of it: The social construction of power politics. International Organization 88 (2):384-396.

Wendt, Alexander. 1996. Identity and Structural Change in International Politics. In The Return of Culture in IR Theory, edited by Y. Lapid and F. Kratochwil: Lynne Rienner Publishers, 47-64.

Wendt, Alexander. 1999. Social Theory of International Politics. Cambridge: Cambridge University Press.

Wight, Martin. 1966. Western Values in International Relations. In Diplomatic Investigations, edited by H. Butterfield and M. Wight. London, 89-131.

Windhoff-Héritier, Adrienne. 1980. Politikimplementation: Ziel und Wirklichkeit politischer Entscheidungen. Königstein/Taunus: Hain.

Young, Oran R. 1999. Institutional Dimensions of Global Environmental Change. Science Plan, IHDP Report Series No 9. Bonn: International Human Dimensions Programme on Global Environmental Change.

Zangl, Bernhard. 1994. Politik auf zwei Ebenen. Hypothesen zur Bildung internationaler Regime. Zeitschrift für Internationale Beziehungen 1 (2):279-312.

Zürn, Michael. 1997. "Positives Regieren" jenseits des Nationalstaates. Zeitschrift für Internationale Beziehungen 4 (1):41-68.

Zürn, Michael. 2000. Introduction - Law and Compliance at Different Levels. Manuscript. 
Zürn, Michael, and Christian Joerges. 1999. The Study of Compliance - A Framework. Manuscript.

Zürn, Michael, and Dieter Wolf. 1999. European Law and International Regimes: The Features of Law Beyond the Nation State. European Law Journal 5 (3):272-292. 